\title{
THE MIGRATION OF TWO SYMPATRIC GAMMARID SPECIES IN A FRENCH ESTUARY
}

\author{
by \\ H. B. GIRISCH, J. C. DIELEMAN, G. W. PETERSEN \& S. PINKSTER \\ Institute of Taxonomic Zoology, University of Amsterdam, The Netherlands \\ Station Biologique, 29211 Roscoff, France
}

\begin{abstract}
SUMMARY
1. The migration of two sympatric estuarine species has been studied over a period of one year in the estuary of the river Dourduff, a small river draining into the Bay of Morlaix (Brittany, France). One species, Gammarus zaddachi, is a boreal species and the other, Gammarus chevreuxi, is a lusitanian species. Both species live near the limits of their distribution area.
\end{abstract}

2. Both species show a migration pattern with an anadromous and a catadromous phase. The migration is an active process. The animals use the tidal movements for their upstream and downstream migration.

3. Migration activities of both species show a diurnal rhythm, the activity peak occurring at night.

4. Downriver migration of both species can be observed throughout the whole year. Upstream migration, however, only takes place during periods with high water spring tide. During these periods the stream reverses direction and water with higher salinities enters the limnic parts of the river.

5. Per night the maximum numbers of anadromous and catadromous migrating individuals caught in a net of $30 \times 50 \mathrm{~cm}$ were 30,000 and 800,000 respectively for $G$. chevreuxi. For $G$. zaddachi these numbers are considerably lower.

6. In both species the composition of the samples from upstream and downstream catches were different. In general, upstream migrating animals are smaller and younger than downstream migrating individuals.

7. $G$. zaddachi invades the limnic reaches of the river only when water temperatures drop below $6-8^{\circ} \mathrm{C}$, a situation occurring for a period of only a few weeks.

8. $G$. zaddachi reproduces only during the winter months when water temperatures are relatively low. Reproduction takes place in areas with constant or at least periodical influence of mixohaline waters. In the limnic reaches of the Dourduff reproduction is never observed.

9. G. chevreuxi migrates farther upstream than G. zaddachi. It can stay in completely fresh water for more than four months.

10. G. chevreuxi can reproduce during the whole year. Reproduction has never been observed in completely fresh areas, although downstream migrating ovigerous females can be found.

11. In a series of laboratory experiments, survival rates and reproduction capacity were determined under various different temperature/salinity conditions.
12. Temperature has a strong influence on the salinity tolerance of $\mathrm{G}$. zaddachi. At $5^{\circ} \mathrm{C}$ the mortality rate in river water is comparable to that under optimal salinity conditions. At higher temperatures the mortality sharply increases at lower salinities.

13. Increasing salinity as well as decreasing temperatures have a positive influence upon the reproduction rate of G. zaddachi. In rearing experiments no reproduction has been observed in limnic (= natural) water of the Dourduff, at $5^{\circ} \mathrm{C}$.

14. For $G$. chevreuxi the situation is different. At $5^{\circ} \mathrm{C}$ survival is low at all salinities. Under brackish conditions $(0.8 \%$ and $8.0 \% 0 \mathrm{Cl})$ a rise in temperature results in a higher survival rate. In fresh water however $(0.08 \% \mathrm{Cl})$, rise of temperature causes a higher mortality rate.

15. In rearing experiments $G$. chevreuxi does not reproduce in completely fresh water. Under mixohaline conditions reproduction has been observed at all temperatures examined.

16. The reproduction cycle of the two species is shown in diagrammatic models.

\section{RESUME}

1. Pendant un an on a étudié la migration de deux espèces estuariennes sympatriques dans l'estuaire du Dourduff, petit confluent de la Baie de Morlaix (Bretagne, France). L'une des deux espèces, Gammarus zaddachi est boréale, l'autre, Gammarus chevreuxi, est lusitanienne. Les deux espèces vivent près des limites de leur aire de distribution.

2. Les deux espèces montrent un modèle de migration comprenant une phase anadrome et une phase catadrome. La migration est un processus actif. Les animaux mettent les courants de marée à profit pour leur migration en amont et en aval.

3. Les activités migratoires des deux espèces montrent un rythme diurne avec une activité maximum pendant la nuit.

4. Pendant toute l'année on peut observer la migration en aval des deux espèces. Par contre, la migration en amont n'a lieu que dans les périodes de grandes marées, lorsque la direction du courant se retourne et que des eaux à plus grande salinité entrent dans les parties limniques de la rivière.

5. Les plus grands nombres d'individus anadromes et catadromes migrant en une seule nuit et captés dans un filet de $30 \times 50 \mathrm{~cm}$ étaient resp. de 30.000 et de 80.000 
(pour G. chevreuxi). Pour G. zaddachi, ces nombres sont considérablement inférieurs.

6. Pour les deux espèces il y eut une différence dans la composition des échantillons de l'amont et de l'aval. En général, les animaux migrant en amont sont plus petits et plus jeunes que ceux migrant en aval.

7. G. zaddachi ne pénètre dans les parties limniques de la rivière que lorsque les températures de l'eau baissent au-dessous de $6-8^{\circ} \mathrm{C}$; une situation qui ne se produit que pendant des périodes intermittentes de quelques semaines.

8. G. zaddachi ne se reproduit que pendant les mois d'hiver lorsque les températures de l'eau sont relativement basses. La reproduction se fait dans des aires où il y a une influence permanente ou au moins périodique d'eaux mixohalines. Dans les parties limniques du Dourduff on n'a jamais observé de reproduction.

9. G. chevreuxi migre plus en amont que G. zaddachi. Il peut rester en eau complètement douce pendant plus que quatre mois.

10. $G$. chevreuxi peut se reproduire pendant toute l'année. On n'a jamais observé cette espèce se reproduisant dans ce milieu d'eau douce, bien qu' on puisse trouver des femelles ovigères migrant en aval.

11. Dans une série d'expériences au laboratoire on a déterminé les degrés de survivance et de la capacité de reproduction dans des conditions différentes de température et de salinité.

12. L'influence de la température est considérable sur le degré de tolérance de la salinité de $G$. zaddachi. A $5^{\circ} \mathrm{C}$ la proportion de mortalité en eau de rivière est comparable à celle qu'on trouve dans des conditions de salinité optimales. A des températures plus élevées la mortalité augmente rapidement à mesure que les salinités baissent.

13. L'augmentation de la salinité et une baisse de la température ont toutes deux une influence positive sur la reproduction de $G$. zaddachi. Dans des expériences d'élevage on n'a pu, non plus, observer de reproduction dans l'eau limnique du Dourduff à $5^{\circ} \mathrm{C}$.

14. Quant à $G$. chevreuxi la situation est différente. A $5^{\circ} \mathrm{C}$ la survivance est basse à toutes les salinités. Dans un milieu saumâtre $(0,8 \%$ et $8 \% \circ \mathrm{Cl})$ une augmentation de la température est plus favorable à la survivance. Dans l'eau douce par contre $(0,08 \% \mathrm{Cl})$ une élévation de température cause une plus grande mortalité.

15. Dans des expériences d'élevage $G$. chevreuxi ne se reproduit pas dans des eaux entièrement douces. Dans des conditions mixohalines on a observé une réproduction à toutes les températures observées.

16. Des diagrammes représentent les cycles de reproduction des deux espèces.

\section{INTRODUCTION}

In the last 20 years much work has been done on the migration of aquatic animals. In most of the papers two phenomena are discussed viz. passive downstream transport ("organic drift") and active migration. An excellent review of the work done in fresh running waters is given by Meyering (1972). In waters of this type, conditions are fairly stable as far as salinity and the direction of the water current are concerned.

In 1969 Dennert et al. described the upstream and downstream migration of the amphipod species Gammarus zaddachi in the estuary of the river Slack, a small stream along the French Channel coast. It was shown that these upstream and downstream movements occurred only at night and that the process was closely correlated to population dynamics, the reproduction cycle and the developmental stage of the animals. Evidence was given that the migration was an active process, although the animals utilized the tidal movements. It appeared that many environmental factors such as salinity, temperature, light and stream velocity had a considerable influence upon the migration of the species but an overall explanation could not be given.

In their 1974 paper, Dennert \& van Maren published the results of some further investigations into these problems, mainly confirming the results obtained in the previous work. In addition to the field work, laboratory experiments were carried out to determine the influence of $\mathrm{Cl}$ - and $\mathrm{Ca}$-ions upon the survival rate and the reproduction rate of G. zaddachi. It was found that a rise in Ca-ions, and especially $\mathrm{Cl}$-ions, has a positive effect upon both the survival rate and reproduction of $\boldsymbol{G}$. zaddachi.

Meanwhile some sampling has been done in other estuaries in France by Dennert \& van Maren (unpublished). They found that two gammarid species, $G$. zaddachi and $G$. chevreuxi, both showing a migration, coexisted in the estuarine parts of the river Dourduff, a small stream draining into the Bay of Morlaix in the northwestern part of Brittany (Bretagne, France). The first species, which is identical to that examined in Dennert's work, is a boreal species having its southernmost distribution in the French Département Vendée (Gras \& Maasen, 1971). In contrast, the other species is a southern (lusitanian) one, occurring along the Atlantic coast from southern Morocco to the southern coasts of England and Eire.

The situation of two migratory species, both living near the limits of their distribution range in an estuary with a temperature regime showing considerable differences from that described by Dennert et al., seemed interesting enough to warrant a continuation of the studies of migratory problems in the estuary of the river Dourduff. These investigations were aimed at providing answers to the following questions:

1. Is the migration pattern shown by $G$. zaddachi 
in this part of France identical to that previously described by Dennert et al., in the northern parts of France?

2. Are there any differences in migration pattern between the two species? If so, this would be an argument against accidental transport.

3. What is the influence of environmental factors such as salinity and temperature upon the migratory movements of the two species?

Over a period of one year field experiments were carried out at regular intervals to give an answer to the first two questions. To solve the third problem, rearing experiments were carried out in the laboratory under different temperature/ salinity conditions, all comparable to situations found in the natural environment, in order to complete data obtained from the field. During these experiments the survival rate and reproduction of both species were determined as a measure of the influence of both environmental factors.
Field observations

\section{STUDY AREA AND PHYSICAL FACTORS}

\section{1. Study area}

Our field observations were carried out over a period of one year in the river Dourduff, a stream in the northwestern part of Brittany (Bretagne), France. This stream is fed by some springs, but principally by the rain. The area in which the investigations were carried out lies in the lower parts of the river system, where the stream flows into a $4 \mathrm{~km}$ long branch of the estuary of the river Morlaix (see fig. 1). Between the estuarine and limnic parts of the river a dam has been constructed in which an old water mill is situated. The river water can pass through three openings. At low tide there is a fall of about $50 \mathrm{~cm}$. Upstream from this dam the river is about 5 to $6 \mathrm{~m}$ wide; its depth varies from 10 to $40 \mathrm{~cm}$, depending

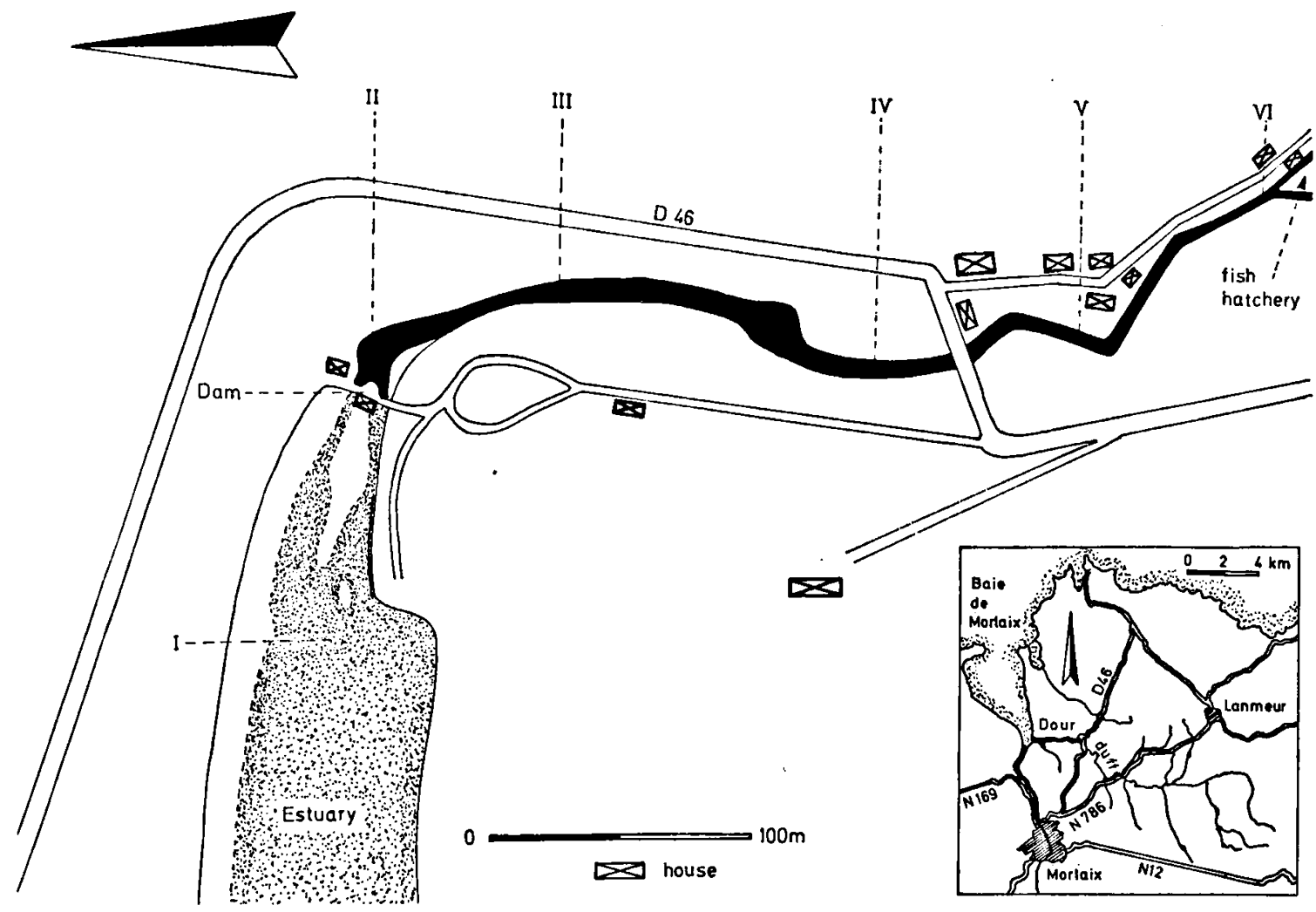

Fig. 1. The lower parts of the river Dourduff where the river drains into the estuary. The Roman numerals indicate the stations. Other numerals denote National and Departemental roads. Dotted: estuarine areas. 
on rainfall. The bottom of the estuary is stony in the first $100 \mathrm{~m}$ downstream from the dam. Further downstream it consists of soft mud. The river water is often polluted by waste water from a fish hatchery which is situated $150 \mathrm{~m}$ upstream from the bridge in road no. D 46 (see fig. 1).

In the area investigated 3 gammarid species can be found viz. Gammarus zaddachi Sexton, 1912, Gammarus chevreuxi Sexton, 1913, and Echinogammarus berilloni (Catta, 1878).

In this area, six "stations" were chosen and numbered I to VI as illustrated in fig. 1. Station I was situated downstream from the dam, in an area where the tides can enter freely and salinity changes twice a day from almost fresh to marine. Station II was situated in one of the openings of the dam. Finally, stations III to VI were situated upstream from the dam, in a part of the river that is influenced by estuarine waters at H.W.S. ${ }^{1}$ ) only.

Sampling was carried out at regular intervals at every station from May 1971 till June 1972 during periods of spring tides. From June 1971 to December 1971 the periods of full moon were used. During the month of December 1971 sampling was carried out over a longer period, including full moon and new moon spring tides as well as a period of neap tides. From January 1972 till June 1972 the observations were made at the periods during new moon.

\section{2. Physical factors}

Along the north coast of Brittany the tides are fairly high, resulting in differences of about 10 metres between high and low water during the equinoctial spring tides and 5 or 6 metres at normal neap tides. These enormous tidal differences make the area investigated a kind of "shock biotope".

During H.W.S. a brackish water tidal area and a smaller freshwater tidal area can develop in the first few hundred metres upstream from the dam. During these periods, salinities of up to $17 \% \mathrm{Cl}$ were measured at station $\mathrm{V}$ and in autumn at station VI as well. These waters with a higher salinity enter the limnic parts of the river just above the bottom. The water at the surface almost never attains these high salinities. In periods with small supplies of river water a freshwater tidal area can hardly ever be observed. It is only in winter, during heavy rainfall, that such a freshwater tidal area can develop. Even under these

1) H.W.S. = high water spring tide.

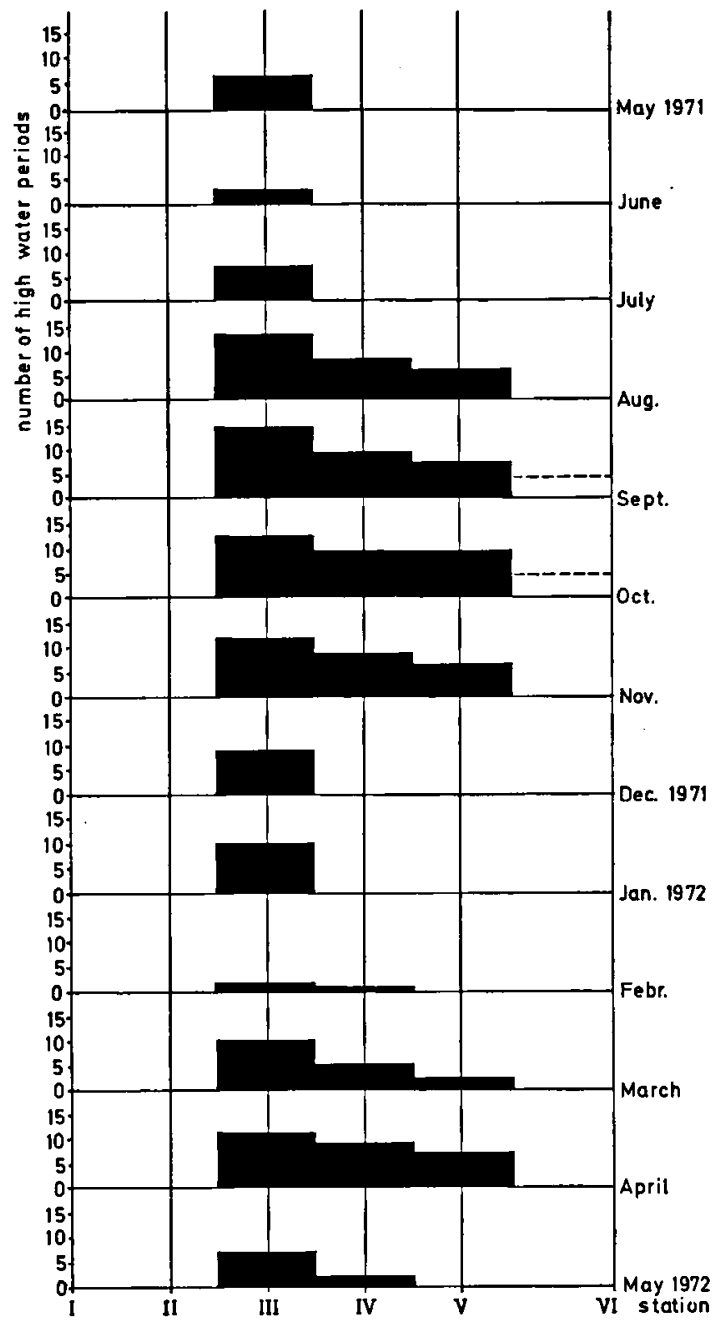

Fig. 2. The number of high water periods per month during which water with an elevated salinity reached the stations upstream from station II every month throughout the period of investigation.

extreme conditions a reverse of the freshwater current is hardly ever observed. In these instances the riverbed gradually fills up with fresh water, forming an almost stagnant pool. When this happens saline waters can hardly penetrate into the area upstream from the dam.

Fig. 2 shows the number of times that waters with an elevated salinity reached the stations upstream from station II during the period of investigation. The influence of the equinoctial tides (Aug.-Nov., March-April) and the freshwater supply (May-July, Dec.-Jan.) is clearly visible in this figure. Fig. 3, showing the stream velocity at the stations upstream from the dam gives an impression of the freshwater supply. 


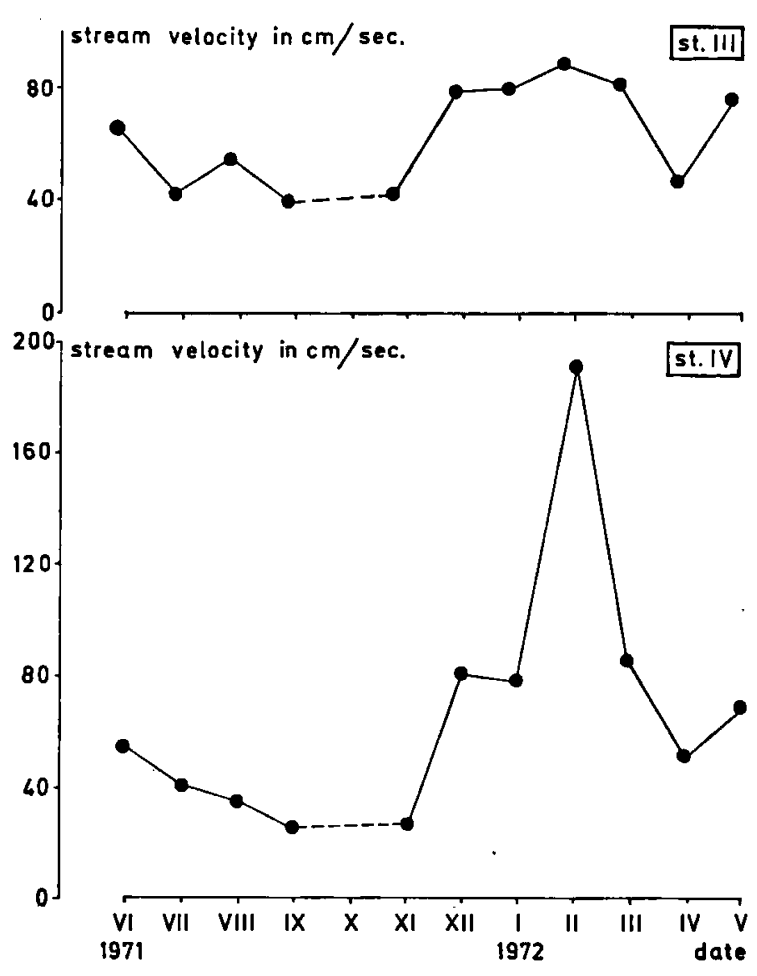

Fig. 3. The stream velocity at the surface at the stations III and IV as measured on various dates throughout the period of investigation.

The chlorinity of the river water is almost constant throughout the year $(33-40 \mathrm{mg} / \mathrm{l})$. The $\mathrm{pH}$ of the river water is also fairly constant (7.3-7.5). The $\mathrm{Ca}$ content, however, shows considerable changes ranging from 13 to $30 \mathrm{mg} / \mathrm{l}$, but no explanation for this phenomenon could be found.

The maximum and minimum temperatures of the river water throughout the year are illustrated in fig. 4. It must be emphasized that although the water temperature sometimes falls below $7.5^{\circ} \mathrm{C}$, it never stays at this level over a long period.

It must be assumed that salinity changes in the almost stagnant water between the gravel of the upper bottom layers, where the gammarids normally live, are less extreme than in the overflowing river water (Mangelsdorf, 1967; Nooter \& Liebregts, 1971). Technical problems made it impossible to sample this stagnant water between the gravel at regular intervals and only some incidental measurements were made. At station III it was found that 12 hours after the last direct influence of saline water the chlorinity of the interstitial water was still $500 \mathrm{mg} / \mathrm{l}$. It took 3 days before the chlorinity of the interstitial water had dropped to the level of "normal" river water.

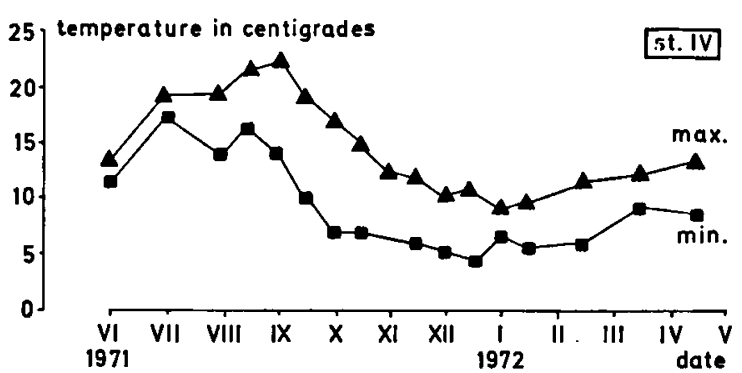

Fig. 4. The monthly maximum and minimum temperatures of the water at station IV.

\section{MICROHABITAT OF THE GAMMARUS POPULATION}

Dip net catches proved that the populations of the two species were not randomly dispersed throughout the riverbed. A correlation could be found between the size of the animals and the composition of the substrate. Juveniles of $G$. zad$d a c h i$ and $G$. chevreuxi can be found in fine substrata, usually in the middle of the stream. In the coarse gravel near the riverbanks G. zaddachi, fully grown adults of $G$. chevreuxi, and precopulations of $G$. chevreuxi are dominant in the catches. The largest specimens of $G$. zaddachi are predominantly found under stones. Moreover, G. zaddachi seems to prefer higher stream velocities than G. chevreuxi (cf. Salmon, 1959; den Hartog, 1964). In summertime large amounts of G. chevreuxi can be found between Enteromorpha.

\section{METHODS}

\section{IV.1. Nets}

During these experiments use was made of combination nets with a rectangular aperture of $30 \times$ $50 \mathrm{~cm}$, as described by Dennert et al. (1969). In catching downstream migrating animals, the top of the net was always projecting from the water, thus catching migrating animals in the whole water column.

At station I, where the net could not be lifted during H.W. because of the enormous amounts of water, an adapted net was used. In this net the interchangeable bag in which the animals were caught is automatically closed by a "rudder" (see fig. 5) when the direction of the stream reverses to prevent the catch from being washed away. Control experiments at station I with this type of 


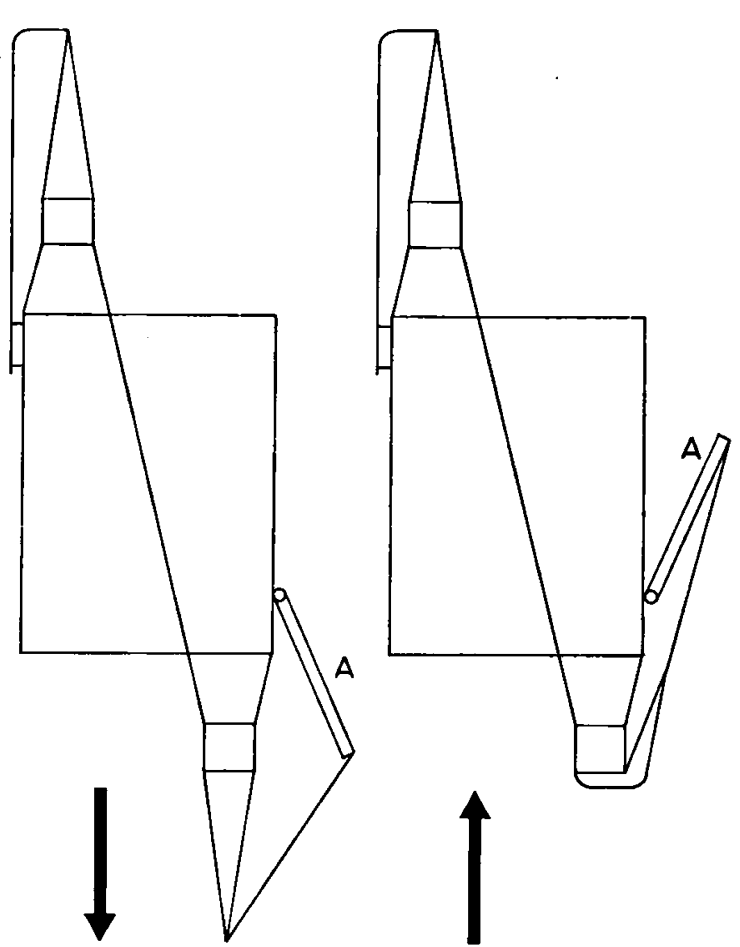

Fig. 5. Diagram showing the combination net from above with an interchangeable bag adapted for use in the estuary. The interchangeable bag is closed or opened by a "rudder" (A) when the direction of the stream reverses. The adapted bag is shown in the position to catch animals (left) and in the position to prevent the caught animals to be washed away after the reversal of the stream direction (right). The arrows indicate the direction of the stream.

net proved that less than $50 \%$ of the catch was lost in this way. To complete the data obtained with these combination nets, dip net samples were taken with rectangular nets of $18 \times 12 \mathrm{~cm}$, mesh size $1.0 \times 1.5 \mathrm{~mm}$. Every month all the different microhabitats at the various stations were examined in order to get information about the standing crop.

\section{IV.2. Physicochemical determinations}

Chlorinity was determined in $\mathrm{mg} / \mathrm{l}$ with the aid of an E.E.L. electrical device. Both surface and bottom chlorinities were determined. The $\mathrm{Ca}$ and $\mathrm{Mg}$ content were determined with the aid of an Oxford titrator (E.D.T.H. method). The pH was measured electrically with a Metrohm pH-meter type E 488. Stream velocity was estimated at the surface using a floating object and a stop watch. Temperature readings were taken with a maximum/minimum mercury thermometer. Interstitial water was collected by centrifuging the bottom sample.

\section{IV.3. Further treatment of the material}

Random subsamples were taken from a series of samples and the animals thus obtained were divided into four groups: juveniles (animals that could not be sexed), males, females and ovigerous females. For $G$. zaddachi we grouped according to the criteria developed by Dennert et al. (1969), for $G$. chevreuxi we used the criteria of Sexton (1924).

Since the animals have a bent, comma-shaped, body, the length of the cephalic segment was used as a measure of the body length, a method described by Dennert et al. (1969). Dennert et al. showed a linear correlation between the body length and the cephalic length to be present, although both Sutcliffe (1972) and van den Beld (1973) pointed out, that the correlation was somewhat more complicated than shown in Dennert's paper. For $G$. chevreuxi, our data correspond closely with their findings, viz. the relation can be described by two linear correlations, one for juveniles and another for adults as illustrated in fig. 6 .

The mean of the cephalic lengths and their standard deviations were calculated for every random sample. The differences found between the samples were tested statistically with the $t$ test.

\section{Results}

\section{MIGRATORY ACTIVITY}

Both species, G. zaddachi and $G$. chevreuxi, show migratory activities in the area investigated. These migration patterns can be divided into an anadromous and a catadromous phase. It must be stressed that in the context of this paper the term "upstream migration" is meant in a geographic sense and not in the sense that animals are actively migrating upstream against the direction of the river flow. On the contrary, as will be discussed in section VIII, the animals use the water currents for their upstream and downstream movements.

\section{V.1. Downstream migration}

It has been demonstrated by many authors (e.g. Müller, 1965, 1970; Waters, 1965; Dennert et al., 


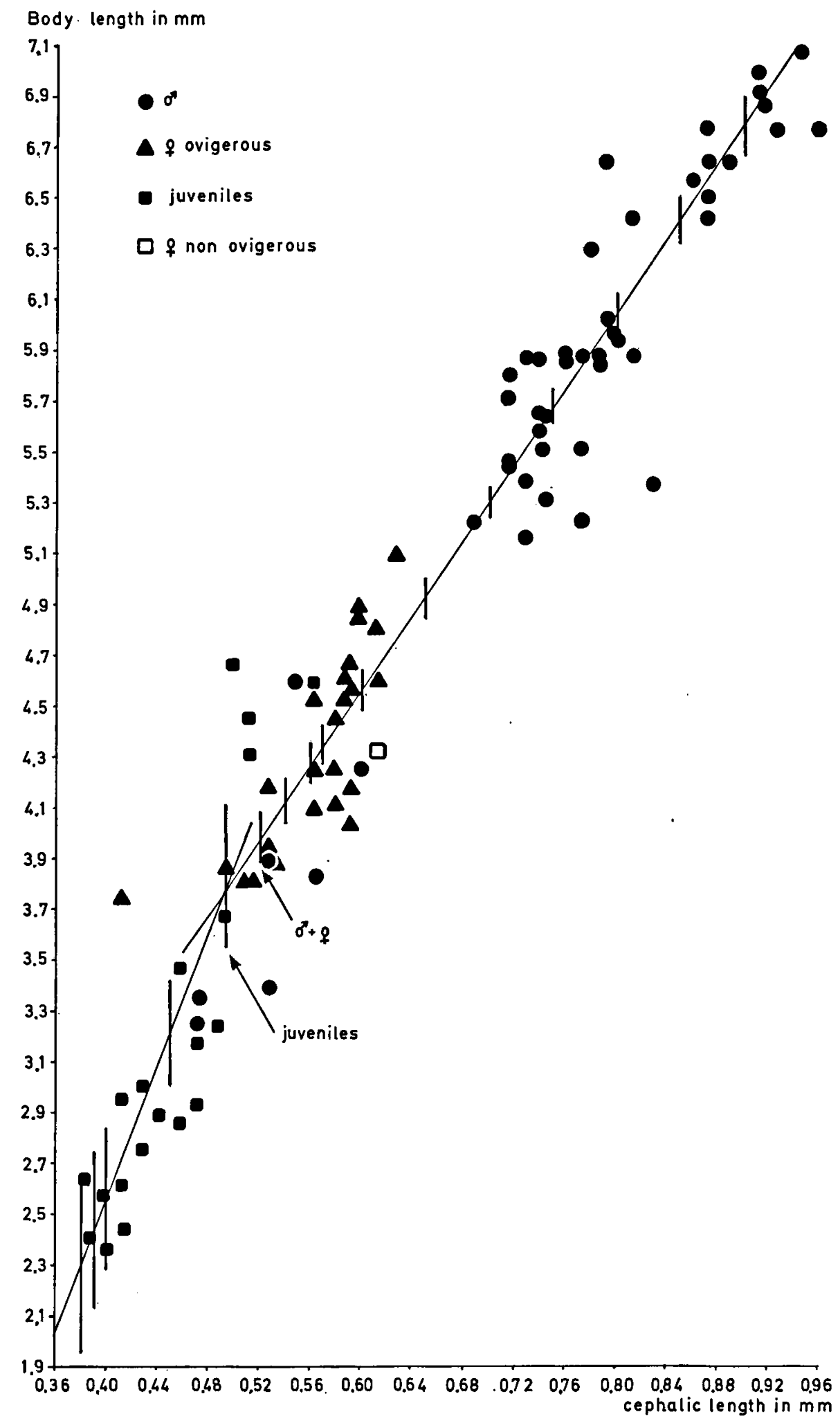

Fig. 6. The relation between body length and cephalic leng th in Gammarus chevreuxi. Two linear regression lines are calculated: one for adults and one for juveniles. The vertical lines indicate the $95 \%$ probability intervals. 
1969) that downstream migrating gammarids show a day-night periodicity, with the following regularities. (1) Downstream migration only takes place at night. (2) The activity starts about one hour after sunset and reaches a maximum some two or three hours after sunset. (3) The activity gradually diminishes during the rest of the night and stops completely about one hour before sunrise.

The situation found for $G$. zaddachi and $G$. chevreuxi in the Dourduff is no exception to this rule. In summer the situation is almost identical to that demonstrated by Dennert et al. (1969) in their figs. 12, 13, and 14. In winter, when nights are long, the situation is somewhat different in that there is no sharp peak some two hours after sunset, activity being more or less spread over the whole night.

Sampling at brief intervals during the month of December 1971 revealed that downstream migration continues during the whole month, though the pattern is disturbed by the stream velocity. It seems that an increase of stream velocity has a negative effect on downstream migration (cf. Hughes, 1970; Minshalt \& Winger, 1968).

No evidence could be found to show that downstream migration is influenced by penetrating saline waters or by changes in light intensity. It may be that laboratory experiments can provide answers to these problems.

\section{V.2. Upstream migration}

Both species show upstream migration activity corresponding to that described by Dennert et al., that is, upriver movements only take place when the direction of the water currents reverses because of the incoming tide. Apparently, the animals simply utilize the water movements for their displacements. Like downstream migration, this activity only occurs at night. During the nights that upstream migration could be observed, this feature was accompanied by an increase of chlorinity near the bottom. It is not yet clear whether upstream migration is possible in the freshwater tidal area of the Dourduff. Sampling with nets at various distances from the bottom showed that this type of migration is restricted to the bottommost $50 \mathrm{~cm}$ of water. This means that the number of animals caught in a net placed on the bottom gives a good impression of the total number of upstream migrating animals.

\section{NUMBER OF MIGRANTS AT THE VARIOUS STATIONS}

\section{VI.1. Gammarus chevreuxi}

Every month throughout the period of investigation a sample of downstream migrating animals was taken at every station in the course of one night. The number of individuals in these catches is shown in table $\mathrm{I}$.

Moreover (with few exceptions) monthly samples were taken of animals moving upstream at the various stations during $H . W$. periods when upstream migration could be expected. The numbers of individuals migrating upriver during one H.W. period are shown in table I. Assuming that a reversal of the stream during the night is required

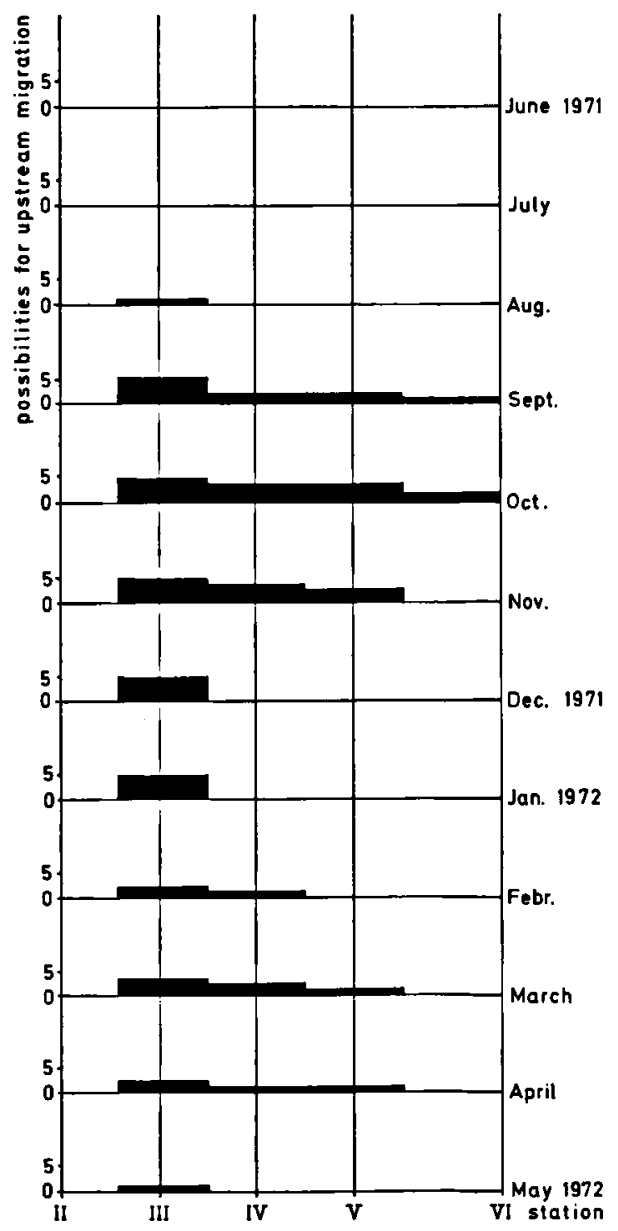

Fig. 7. The number of high water periods per month during which upstream migration is possible at the stations III, IV and V, assuming that a reversal of the stream at night is required for upstream migration.

作 
Table I. Number of upstream and downstream migrants of Gammarus chevreuxi at the various stations.

\begin{tabular}{|c|c|c|c|c|c|c|c|c|c|c|}
\hline \multirow[t]{2}{*}{ Station } & \multicolumn{2}{|c|}{ I } & \multicolumn{2}{|l|}{ II } & \multicolumn{2}{|c|}{ III } & \multicolumn{2}{|l|}{ IV } & \multicolumn{2}{|l|}{$\mathbf{v}$} \\
\hline & down & up & down & up & down & up & down & up & down & up \\
\hline June '71 & $?$ & $?$ & $\begin{array}{l}(12) \\
6,400\end{array}$ & - & $\begin{array}{l}(10) \\
5,000\end{array}$ & - & $\begin{array}{l}(9) \\
1,052\end{array}$ & - & $\begin{array}{l}(11) \\
64\end{array}$ & - \\
\hline July '71 & $?$ & $?$ & $\begin{array}{l}(11) \\
8,150\end{array}$ & - & $\begin{array}{l}(10) \\
29,000\end{array}$ & - & $\begin{array}{l}(8) \\
185\end{array}$ & - & $\begin{array}{l}(9) \\
9\end{array}$ & - \\
\hline Aug. '71 & $?$ & $?$ & $\begin{array}{l}(7) \\
3,126\end{array}$ & $?$ & $\begin{array}{l}(8) \\
2,260\end{array}$ & $?$ & $\begin{array}{l}(9) \\
120\end{array}$ & - & $\begin{array}{l}(6) \\
0\end{array}$ & - \\
\hline Sept. '71 & $\begin{array}{l}(9) \\
33\end{array}$ & $?$ & $\begin{array}{l}(6) \\
572\end{array}$ & $?$ & $\begin{array}{l}(5) \\
1,130\end{array}$ & $\begin{array}{l}(6) \\
180,000 \\
\text { total } \\
490,000\end{array}$ & $\begin{array}{l}(5) \\
165\end{array}$ & $?$ & $\begin{array}{l}(8) \\
870\end{array}$ & $?$ \\
\hline Oct. '71 & $\begin{array}{l}(4) \\
42\end{array}$ & $\begin{array}{l}(5) \\
5\end{array}$ & $\begin{array}{l}\text { (7) } \\
250\end{array}$ & ? & $\begin{array}{l}(5) \\
160\end{array}$ & $\begin{array}{l}(4) \\
7,650 \\
\text { total } \\
39,300\end{array}$ & $\begin{array}{l}(7) \\
46\end{array}$ & $\begin{array}{l}(4) \\
245,000 \\
\text { total } \\
835,000\end{array}$ & $\begin{array}{l}(4) \\
365\end{array}$ & $\begin{array}{l}(5) \\
231,000 \\
\text { total } \\
793,000\end{array}$ \\
\hline Nov. '71 & $\begin{array}{l}(1) \\
4\end{array}$ & $\begin{array}{l}(2) \\
1\end{array}$ & $\begin{array}{l}(4) \\
38\end{array}$ & $\begin{array}{l}(4) \\
5,000\end{array}$ & $\begin{array}{l}(2) \\
340\end{array}$ & $\begin{array}{l}(3) \\
1,200 \\
\text { total } \\
4,400\end{array}$ & $\begin{array}{l}(4) \\
415\end{array}$ & $\begin{array}{l}(5) \\
406 \\
\text { total } \\
3,400\end{array}$ & $\begin{array}{l}(1) \\
3,700\end{array}$ & $\begin{array}{l}(2) \\
180,000 \\
\text { total } \\
540,000\end{array}$ \\
\hline Dec. '71 & $\begin{array}{l}(3) \\
145\end{array}$ & $\begin{array}{l}(4) \\
93\end{array}$ & $\begin{array}{l}(3) \\
880\end{array}$ & $\begin{array}{l}(4) \\
256\end{array}$ & $\begin{array}{l}(8) \\
6,710\end{array}$ & $\begin{array}{l}(5) \\
12,000 \\
\text { total } \\
109,000\end{array}$ & $\begin{array}{l}(2) \\
\left.650^{*}\right)\end{array}$ & - & $\begin{array}{l}(8) \\
4,400\end{array}$ & - \\
\hline Jan. '72 & $\begin{array}{l}(20) \\
400\end{array}$ & $\begin{array}{l}(21) \\
27\end{array}$ & $\begin{array}{l}(21) \\
11,600\end{array}$ & $\begin{array}{l}(18) \\
1,100\end{array}$ & $\begin{array}{l}(17) \\
18,500\end{array}$ & $\begin{array}{l}(18) \\
114,000 \\
\text { total } \\
287,000\end{array}$ & $\begin{array}{l}(18) \\
23,360\end{array}$ & $\begin{array}{l}(19) \\
329\end{array}$ & $\begin{array}{l}(18) \\
5,440\end{array}$ & - \\
\hline Febr. '72 & $\begin{array}{l}(17) \\
800\end{array}$ & $?$ & $\begin{array}{l}(16) \\
520\end{array}$ & $?$ & $\begin{array}{l}(15) \\
600\end{array}$ & $\begin{array}{l}(16) \\
5,400 \\
\text { total } \\
10,000\end{array}$ & $\begin{array}{l}(15) \\
35\end{array}$ & $\begin{array}{l}(17) \\
16 \\
\text { total } \\
16\end{array}$ & $\begin{array}{l}(16) \\
15\end{array}$ & - \\
\hline March '72 & $\begin{array}{l}(16) \\
260\end{array}$ & $\begin{array}{l}(17) \\
29\end{array}$ & $\begin{array}{l}(15) \\
865\end{array}$ & $\begin{array}{l}(15) \\
193\end{array}$ & $\begin{array}{l}(16) \\
1,134\end{array}$ & $\begin{array}{l}(15) \\
36,000 \\
\text { total } \\
96,000\end{array}$ & $\begin{array}{l}(15) \\
43\end{array}$ & $\begin{array}{l}(16) \\
46,000 \\
\text { total } \\
96,000\end{array}$ & $\begin{array}{l}(18) \\
55\end{array}$ & ? \\
\hline April ' 72 & $\begin{array}{l}(14) \\
5,470\end{array}$ & $\begin{array}{l}(15) \\
755\end{array}$ & $\begin{array}{l}(12) \\
6,800\end{array}$ & $\begin{array}{l}(13) \\
14,000\end{array}$ & $\begin{array}{l}(14) \\
3,800\end{array}$ & $\begin{array}{l}(13) \\
20,000 \\
\text { total } \\
40,000\end{array}$ & $\begin{array}{l}(13) \\
1,650\end{array}$ & $\begin{array}{l}(14) \\
8 \\
\text { total } \\
8\end{array}$ & $\begin{array}{l}(13) \\
910\end{array}$ & $\begin{array}{l}(14) \\
55,000 \\
\text { total } \\
55,000\end{array}$ \\
\hline May '72 & $\begin{array}{l}(13) \\
6,050\end{array}$ & $\begin{array}{l}(13) \\
678\end{array}$ & $\begin{array}{l}(12) \\
18,850\end{array}$ & $\begin{array}{l}(13) \\
62,000\end{array}$ & $\begin{array}{l}(11) \\
2,700\end{array}$ & $\begin{array}{l}(12) \\
44,000 \\
\text { total } \\
44,000\end{array}$ & $\begin{array}{l}(12) \\
400\end{array}$ & - & $\begin{array}{l}(13) \\
400\end{array}$ & - \\
\hline
\end{tabular}

The number of downstream migrants during one night and the number of upstream migrants during one H.W. period are given, together with dates, for every month during the period of investigation. The days of the months concerned are given in parentheses; "total" reports the estimated total number of upstream migrants during one month (see section VI.1). ${ }^{*}$ ) = the stream velocity during sampling time was extremely high; $?=$ no data available; $-=$ no H.W.S. with reversal of the water current during night time. 
for an upstream migration, it must be concluded that only a few H.W. periods can be used for this purpose. Fig. 7 indicates all the possibilities for upstream migration throughout the year with respect to stations III, IV and V. On the basis of fig. 7 and the number of animals moving up- stream per H.W. period taken from table I we can roughly calculate the total number of upstream migrants in a month at stations III, IV and V.

The numbers of downstream and upstream migrating animals from table $I$ are illustrated in fig. 8. In studying this figure, it is important to

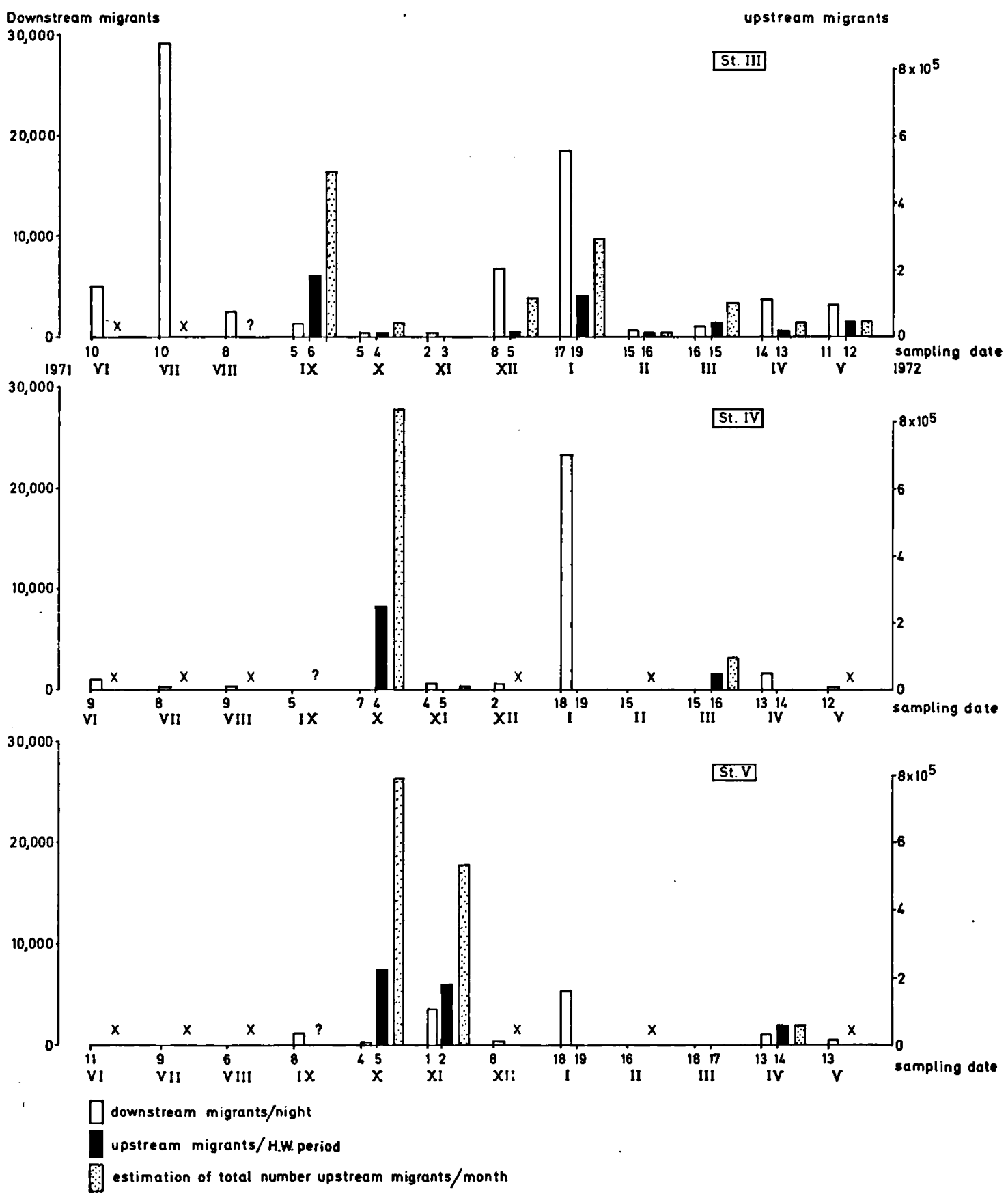

Fig. 8. Numbers of upstream migrating G. chevreuxi per net taken in the course of one H.W. period and numbers of downstream migrating individuals per net during one night at the stations III, IV and V, every month throughout the period of investigation. The data are derived from table $I$. $?=$ no sample taken; $X=$ no H.W.S. with reversal of the water current during the night in this month. The $y$-axis calibrations at the left and right sides relate to downstream and upstream migrants, respectively. 
keep in mind that the $y$-axis calibration of the "downstreamers" is a factor 30 smaller than that of the "upstreamers". If we assume that the downstream migration at a given density of the standing crop only shows gradual changes over the period of a month (see section V.1) then it is possible to get an impression of the total downstream migration per month by multiplying the number of animals found in one net per night by the factor 30 . The selection of the two different scales in fig. 8 enables us to compare the total number of animals migrating upstream and downstream in the course of one month by using the same figure.

Table I shows that downstream migration goes on continuously throughout the year, although considerable changes in numbers can be observed. Station V seems to be the only exception here, but this is not true. The fact is that at this station no downstream migrants can be found during part of the year simply because the area upstream from it is already depopulated at that time.

\section{VI.2. Gammarus zaddachi}

The number of animals migrating downstream per night, the number of animals migrating upstream during one H.W. period and the estimated number of animals migrating upstream in one month are shown in table II. This table is fundamentally the same as table I for G. chevreuxi. The only problem is that in our catches G. zaddachi represented only a very small fraction of the total number of animals, usually no more than a few per mill. Because of the enormous numbers of Gammarus chevreuxi it was often impossible to examine the whole catch. In those cases the individuals of both species in a random sample - i.e. a known fraction of the whole catch - were counted. Very often the number of Gammarus zaddachi in the random sample was very small. The numbers indicated in table II are therefore less reliable than those stated for $G$. chevreuxi in table I. To give an idea of the reliability of the numbers in table II, the numbers of $G$. zaddachi that were really determined, or the size of the random sample as a fraction of the whole catch, are indicated in the table as $n$ and $f$, respectively.

\section{COMPOSITION OF THE MIGRATING POPULATION}

Using part of the samples collected in the drift net, the animals were divided into juveniles, males, females and ovigerous females and the cephalic segments were measured (see section IV.3). With the data thus obtained it is possible to give an answer to the following questions: (1) Does the composition of the migrants change at a certain station in the course of the year ? (2) Is there any difference between upstream and downstream migrants at a given station in the various months? (3) Are there any differences between the samples collected at the various stations at any particular sampling time?

\section{VII.1. Gammarus chevreuxi}

At station III a sample of downstreamers and, if possible, upstreamers was taken every month. Population composition and cephalic lengths were determined from these samples. The results are illustrated in fig. 9. The same was done with the samples from station $\mathrm{V}$ in the months in which the samples were large enough to permit statistical treatment.

The mean of the cephalic lengths and their standard deviations are given in table III. The changes in samples at station III during the year are discussed in section X.1c. Upstream migrating animals at station III are always significantly smaller than downstream migrating animals ( $t$ test, significance 99\%), except for March, 1972. At station $\mathrm{V}$, upstreamers are significantly smaller than downstreamers in April 1972 only. In October and November 1971 their mean lengths were statistically the same. Downstream migrating animals at station $\mathrm{V}$ are smaller than, or equal in size to, those at station III with the exception of October, 1971 (see table III).

\section{VII.2. Gammarus zaddachi}

Since few specimens were available (see section VI.2) it was only possible to determine the composition of a few samples from station III, as is shown in table IV. In the two months in which both upstreamers and downstreamers could be measured, animals migrating upstream were significantly smaller than those going in the other direction.

For the sake of clarity, this paper does not give all the available data concerning the composition of the migrants of both $G$. chevreuxi and $G$. zaddachi at the 6 stations throughout the year or their statistical treatment. These data are deposited in the Institute of Taxonomic Zoology, Amsterdam. 

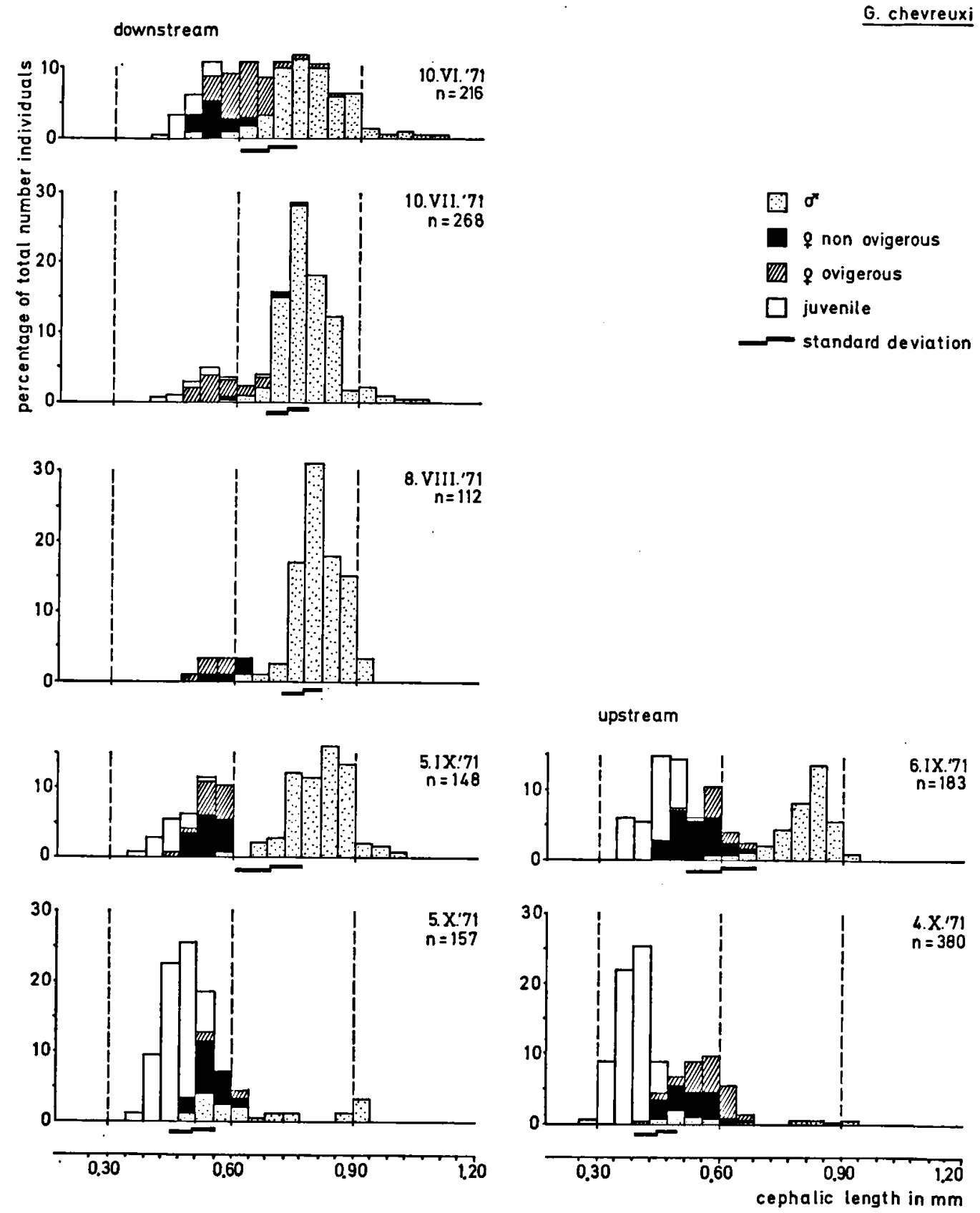

Fig. 9. The population composition, the mean cephalic length and its standard deviation of upstream and down stream migrants of Gammarus chevreuxi at station III (continued on next page).

\section{ACCIDENTAL VERSUS ACTIVE TRANSPORT}

The fact that both upstreamers and downstreamers use the tidal currents suggests that the movements observed are merely accidental passive transportations that can be compared with the "constant drift" mentioned by Waters (1965).
Certain facts, however, support our idea that the movements observed are based on an active behaviour pattern and that the animals can determine the difference between transportation in downstream and upstream direction:

- The migration pattern of Gammarus chevreuxi throughout the year is different from that of Gammarus zaddachi (see section XVI). 

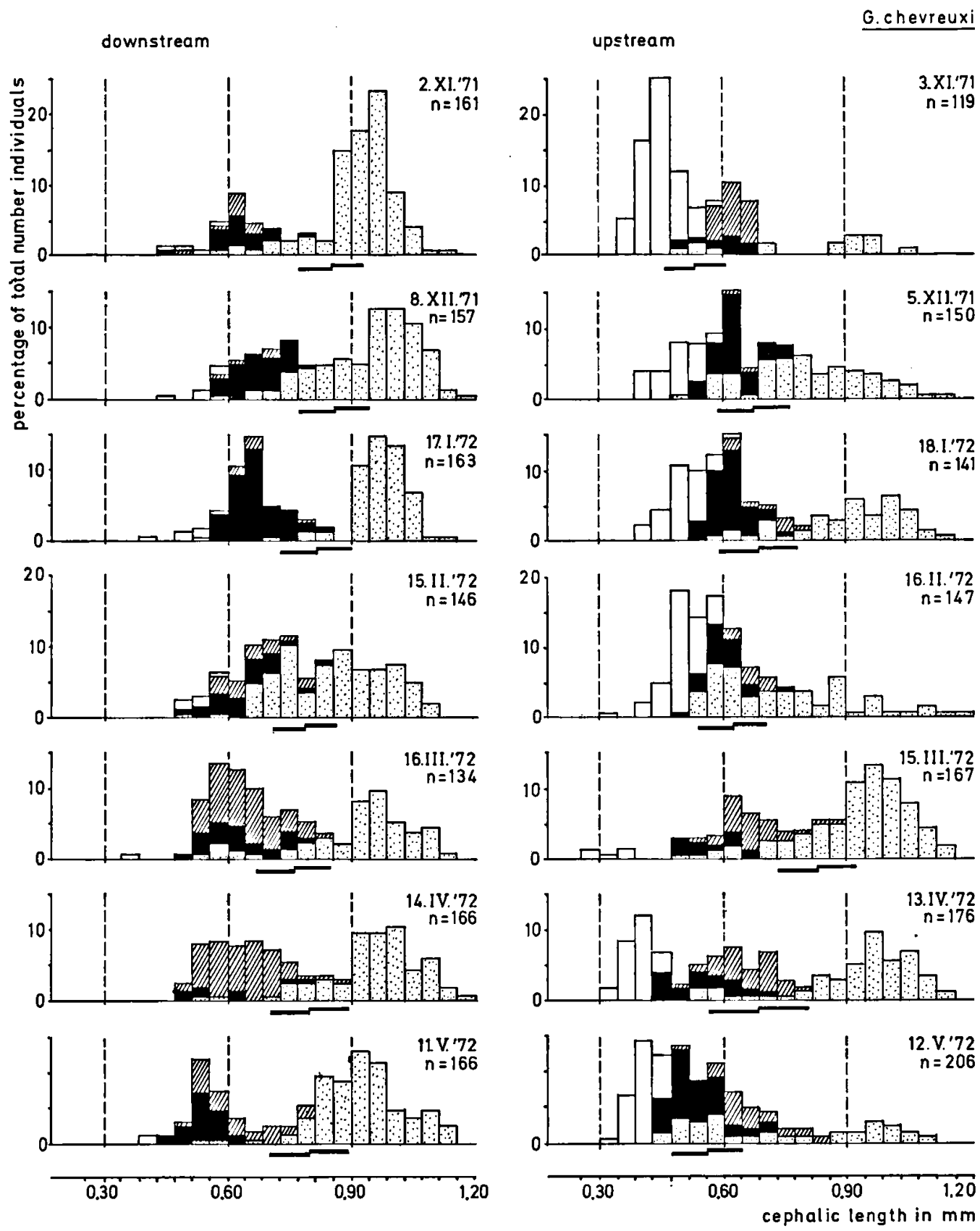

Fig. 9, continued from page 250.

- In certain months enormous numbers of animals move upriver while the downriver migration has almost stopped.

- Apart from some exceptions the upstreamers are significantly smaller than the downstreamers.

- The migration activities of ovigerous females are different from those of non-ovigerous females (see section X.1c).
IX. CHANGES IN THE POPULATION COMPOSITION AT THE VARIOUS STATIONS THROUGHOUT THE YEAR

Dip net samples were taken (see section IV.1) in order to find the effect of migration upon the density of the populations of the two species at the various stations. Since the animals are not random- 
Table II. Number of upstream and downstream migrants of Gammarus zaddachi at the various stations.

\begin{tabular}{|c|c|c|c|c|c|c|c|c|c|c|}
\hline Station & I & & II & & II & & IV & & $\mathbf{v}$ & \\
\hline June '71 & $\begin{array}{l}\text { down } \\
?\end{array}$ & up & $\begin{array}{l}\text { down } \\
(12) \\
19 \\
n=15\end{array}$ & up & $\begin{array}{l}\text { down } \\
(10) \\
49 \\
n=42\end{array}$ & up & $\begin{array}{l}\text { down } \\
(9) \\
59 \\
n=59\end{array}$ & up & $\begin{array}{l}\text { down } \\
(11) \\
0 \\
\mathrm{f}=0.74\end{array}$ & up \\
\hline July '71 & $?$ & $?$ & $\begin{array}{l}(11) \\
183 \\
n=13\end{array}$ & - & $\begin{array}{l}(10) \\
244 \\
n=54\end{array}$ & - & $\begin{array}{l}(8) \\
14 \\
n=11\end{array}$ & - & $\begin{array}{l}(9) \\
10 \\
n=9\end{array}$ & - \\
\hline Aug. '71 & $?$ & $?$ & $\begin{array}{l}\text { (7) } \\
183 \\
n=22\end{array}$ & $?$ & $\begin{array}{l}(8) \\
101 \\
n=11\end{array}$ & $?$ & $\begin{array}{l}(9) \\
2 \\
n=1\end{array}$ & - & $\begin{array}{l}\text { (6) } \\
0 \\
f=0.57\end{array}$ & - \\
\hline Sept. '71 & $\begin{array}{l}(9) \\
30 \\
n=14\end{array}$ & $\begin{array}{l}(9) \\
21 \\
n=21\end{array}$ & $\begin{array}{l}(6) \\
32 \\
n=9\end{array}$ & $?$ & $\begin{array}{l}(5) \\
96 \\
n=19\end{array}$ & $\begin{array}{l}(6) \\
9,500 \\
n=30 \\
\text { total } \\
24,200\end{array}$ & $\begin{array}{l}(5) \\
6 \\
n=5\end{array}$ & ? & $\begin{array}{l}(8) \\
7 \\
n=5\end{array}$ & ? \\
\hline Oct. '71 & $\begin{array}{l}\text { (4) } \\
50 \\
n=26\end{array}$ & $\begin{array}{l}(5) \\
8 \\
n=8\end{array}$ & $\begin{array}{l}(7) \\
34 \\
n=27\end{array}$ & $?$ & $\begin{array}{l}(5) \\
0 \\
f=1.0\end{array}$ & $\begin{array}{l}\text { (4) } \\
0 \\
f=0.027 \\
\text { total } \\
0\end{array}$ & $\begin{array}{l}\text { (7) } \\
0 \\
f=0.62\end{array}$ & $\begin{array}{l}(4) \\
0 \\
2 f=0.002 \\
\text { total } \\
0\end{array}$ & $\begin{array}{l}(4) \\
10 \\
n=7\end{array}$ & $\begin{array}{l}(5) \\
0 \\
f=0.007 \\
\text { total } \\
0\end{array}$ \\
\hline Nov. '71 & $\begin{array}{l}\text { (1) } \\
212 \\
n=47\end{array}$ & $\begin{array}{l}(2) \\
7 \\
n=7\end{array}$ & $\begin{array}{l}(4) \\
22 \\
n=12\end{array}$ & $\begin{array}{l}\text { (4) } \\
178 \\
n=12\end{array}$ & $\begin{array}{l}(2) \\
119 \\
n=53\end{array}$ & $\begin{array}{l}(3) \\
5 \\
n=1 \\
\text { total } \\
33\end{array}$ & $\begin{array}{l}(4) \\
147 \\
n=27\end{array}$ & $\begin{array}{l}(5) \\
3 \\
n=1 \\
\text { total } \\
25\end{array}$ & $\begin{array}{l}(1) \\
10 \\
n=7\end{array}$ & $\begin{array}{l}(2) \\
0 \\
f=0.003 \\
\text { total } \\
0\end{array}$ \\
\hline Dec. '71 & $\begin{array}{l}(3) \\
41 \\
n=21\end{array}$ & $\begin{array}{l}(4) \\
6 \\
n=6\end{array}$ & $\begin{array}{l}\text { (3) } \\
6 \\
n=2\end{array}$ & $\begin{array}{l}(4) \\
2 \\
n=2\end{array}$ & $\begin{array}{l}(8) \\
560 \\
n=235\end{array}$ & $\begin{array}{l}(5) \\
0 \\
5 f=0.05 \\
\text { total } \\
0\end{array}$ & $\begin{array}{l}(2) \\
\left.50^{*}\right) \\
n=3\end{array}$ & $\begin{array}{l}(3) \\
0 \\
\mathrm{f}=1.0 \\
\text { total } \\
0\end{array}$ & $\begin{array}{l}(8) \\
0 \\
f=0.02\end{array}$ & - \\
\hline Jan. '72 & $\begin{array}{l}(20) \\
6 \\
n=1\end{array}$ & $\begin{array}{l}(21) \\
1 \\
n=1\end{array}$ & $\begin{array}{l}(17) \\
304 \\
n=4\end{array}$ & $\begin{array}{l}(18) \\
4 \\
n=2\end{array}$ & $\begin{array}{l}(17) \\
28 \\
n=1\end{array}$ & $\begin{array}{l}(18) \\
46 \\
n=5 \\
\text { total } \\
116\end{array}$ & $\begin{array}{l}(18) \\
340 \\
n=2\end{array}$ & $\begin{array}{l}(19) \\
0 \\
f=1.0 \\
\text { total } \\
0\end{array}$ & $\begin{array}{l}(18) \\
0 \\
f=0.01\end{array}$ & $\frac{-}{18}$ \\
\hline Febr. '72 & $\begin{array}{l}(17) \\
13 \\
n=6\end{array}$ & $?$ & $\begin{array}{l}(16) \\
0 \\
f=0.22\end{array}$ & $?$ & $\begin{array}{l}(15) \\
0 \\
f=0.29\end{array}$ & $\begin{array}{l}(16) \\
10 \\
9 n=10 \\
\text { total } \\
18\end{array}$ & $\begin{array}{l}(15) \\
0 \\
f=0.21\end{array}$ & $\begin{array}{l}(17) \\
0 \\
1 \mathrm{f}=1.0 \\
\text { total } \\
0\end{array}$ & $\begin{array}{l}(16) \\
0 \\
f=0.25\end{array}$ & - \\
\hline March '72 & $\begin{array}{l}(16) \\
2 \\
n=2\end{array}$ & $\begin{array}{l}(17) \\
0 \\
f=1.0\end{array}$ & $\begin{array}{l}(15) \\
8 \\
n=4\end{array}$ & $\begin{array}{l}(15) \\
0 \\
f=1.0\end{array}$ & $\begin{array}{l}(16) \\
25 \\
n=14\end{array}$ & $\begin{array}{l}(15) \\
235 \\
n=7 \\
\text { total } \\
626\end{array}$ & $\begin{array}{l}(15) \\
n=1\end{array}$ & $\begin{array}{l}(16) \\
0 \\
f=0.009 \\
\text { total } \\
0\end{array}$ & $\begin{array}{l}(18) \\
0 \\
f=0.9\end{array}$ & - \\
\hline April '72 & $\begin{array}{l}(14) \\
445 \\
\mathrm{n}=65\end{array}$ & $\begin{array}{l}(15) \\
24 \\
n=24\end{array}$ & $\begin{array}{l}(12) \\
135 \\
n=11\end{array}$ & $\begin{array}{l}(13) \\
120 \\
n=3\end{array}$ & $\begin{array}{l}(14) \\
154 \\
n=11\end{array}$ & $\begin{array}{l}(13) \\
200 \\
\text { total } \\
400\end{array}$ & $\begin{array}{l}(13) \\
22 \\
n=3\end{array}$ & $\begin{array}{l}(14) \\
0 \\
f=1.0 \\
\text { total } \\
0\end{array}$ & $\begin{array}{l}(13) \\
9 \\
n=4\end{array}$ & $\begin{array}{l}(14) \\
1,520 \\
n=38 \\
\text { total } \\
1,520\end{array}$ \\
\hline May '72 & $\begin{array}{l}(13) \\
338 \\
n=53\end{array}$ & $\begin{array}{l}(13) \\
21 \\
n=7\end{array}$ & $\begin{array}{l}(12) \\
708 \\
n=27\end{array}$ & $\begin{array}{l}(13) \\
4,600 \\
n=34\end{array}$ & $\begin{array}{l}(11) \\
248 \\
n=39\end{array}$ & $\begin{array}{l}(12) \\
1,410 \\
n=28 \\
\text { total } \\
1,410\end{array}$ & $\begin{array}{l}(12) \\
38 \\
n=12\end{array}$ & - & $\begin{array}{l}(13) \\
3 \\
n=2\end{array}$ & - \\
\hline
\end{tabular}

$\mathrm{n}=$ the number of animals determined; $\mathbf{f}=$ size of the determined random sample, as a fraction of the total catch (see section VI.2); for further explanations see table I. 
ly distributed over the riverbed (see section III) it is impossible to get a representative sample of the standing crop at a certain station. Accordingly, the data illustrated in figs. 10 (G. chevreuxi) and 11 (G. zaddachi) only give an indication of the composition and density of the population in the area investigated. Some additional data concerning the standing crop that could not be illustrated in figs. 10 and 11 will be discussed in section $X$.

In summertime, when the upper reaches are abandoned by $G$. chevreuxi and $G$. zaddachi, Echinogammarus berilloni invades these areas.

\section{MIGRATION WITH RESPECT TO POPULATION DYNAMICS}

\section{X.1. Gammarus chevreuxi}

\section{X.1a. Reproduction.}

Mass reproduction starts in January in the estuarine parts downstream from the dam. In February and March mass reproduction can be found at stations II and III as well. During the summer months hatching of juveniles goes on in the estuarine area although at a considerable lower level. In November and December reproduction has almost stopped. In general, ovigerous females are only to be found in those parts of the river where waters with higher salinities penetrate at least a few times a month.

X.1b. Population movements in the Dourduff.

From figs. 8 and 10 we can derive a general pattern of the population displacements. From May to September the population mainly inhabits the reaches downstream from station III, i.e. those areas into which mixohaline waters penetrate. A general downstream migration is particularly evident in July. In spring and summer the animals move much further into the open estuary than they do in the winter months, but it was impossible for us to determine the extreme downstream limits of the population because of the inaccessibility of the terrain.

During September, October and November large numbers of animals migrate upstream to and beyond station VI. In the main, these upstream migrants are of small size, most probably being individuals belonging to the new generation born in the estuary during the summer months. In November, almost the entire population at station VI consists of juveniles. During the three months

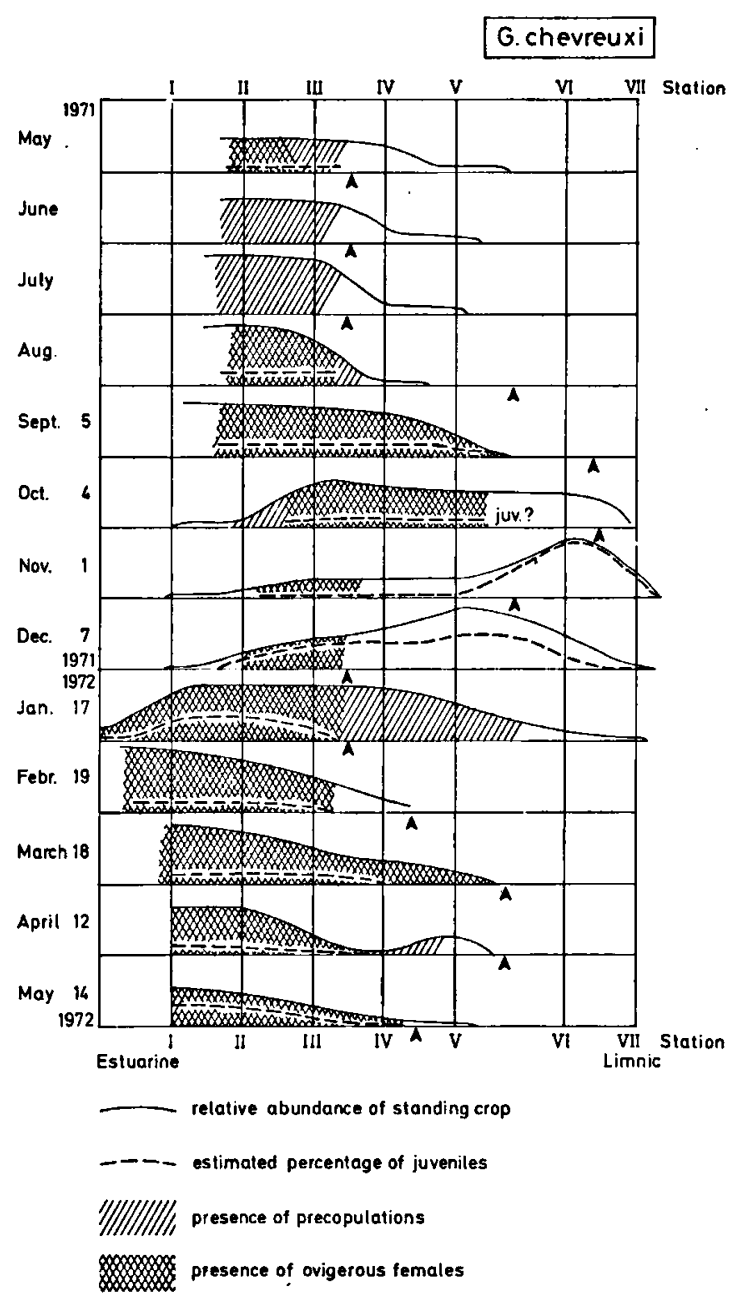

Fig. 10. The composition and estimated abundance of the standing crop of Gammarus chevreuxi at the various stations. Station VII is situated $40 \mathrm{~m}$ upstream from station VI. Arrows indicate the inlandmost influence of the penetration of saline water in the various months. The hatching only indicates the presence and certainly not the percentage of precopulations and ovigerous females.

in which mass upstream migration takes place, downstream migration stops almost completely.

From November till February the animals at stations $\mathrm{V}$ and VI slowly develop into small adults. Almost all the animals in this population are of the same size. In the populations living further downstream nearly all size classes can be found.

A considerable downstream migration can be observed at station III in December and at all stations in January. Explosive reproduction starts in the estuarine parts in January.

Animals from the estuarine parts migrate upstream in the following months and reach station IV in March. A further upstream migration is 
impossible in spring because the current reversal in these months does not reach beyond station $\mathrm{V}$ as can be seen in fig. 7. The number of upstreamers in spring is much lower than in autumn. Meanwhile (in spring) the old generation which has moved in upstream direction in the autumn months slowly migrates further downstream. In
April, while the downstream migration is still going on, an upstream migration can simultaneously be observed at station $V$. The result of these two movements is a kind of spatial gap between the old and new generations at station III and IV. At stations I and II the standing crop consists mainly of large specimens; at stations III and IV

Table III. The mean cephalic lengths and their standard deviations in upstream and downstream migrants of Gammarus chevreuxi at stations III and V.

\begin{tabular}{|c|c|c|c|c|c|c|c|c|c|c|}
\hline \multirow{2}{*}{\multicolumn{2}{|c|}{ date }} & \multirow{2}{*}{\multicolumn{3}{|c|}{\begin{tabular}{l}
\multicolumn{2}{c}{ Station III } \\
downstream date \\
migrants
\end{tabular}}} & \multirow{3}{*}{$\begin{array}{l}\text { upstream } \\
\text { migrants }\end{array}$} & \multirow{2}{*}{\multicolumn{2}{|c|}{ date }} & \multicolumn{2}{|c|}{$\begin{array}{r}\text { Station V } \\
\text { downstream date }\end{array}$} & \multirow[b]{2}{*}{$\begin{array}{l}\text { upstream } \\
\text { migrants }\end{array}$} \\
\hline & & & & & & & & $\begin{array}{l}\text { downstream } \\
\text { migrants }\end{array}$ & date & \\
\hline $10-\mathrm{VI}$ & -1971 & $\begin{array}{l}x=0.679 \\
s=0.132 \\
n=216\end{array}$ & & & & $11-\mathrm{VI}$ & -1971 & $\begin{array}{l}\mathrm{x}=0.582 \\
\mathrm{~s}=0.141 \\
\mathrm{n}=37\end{array}$ & & \\
\hline 10-VII & -1971 & $\begin{array}{l}x=0.731 \\
s=0.106 \\
n=268\end{array}$ & & & & & & & & \\
\hline 8-VIII & I-1971 & $\begin{array}{l}x=0.776 \\
s=0.092 \\
n=112\end{array}$ & & & & & & & & \\
\hline 5-IX & -1971 & $\begin{array}{l}x=0.694 \\
s=0.157 \\
n=148\end{array}$ & 6-IX & -1971 & $\begin{array}{l}x=0.603 \\
s=0.167 \\
n=183\end{array}$ & 8-IX & -1971 & $\begin{array}{l}x=0.665 \\
s=0.121 \\
n=201\end{array}$ & & \\
\hline $5-X$ & -1971 & $\begin{array}{l}x=0.511 \\
s=0.108 \\
n=157\end{array}$ & 4-X & -1971 & $\begin{array}{l}\mathrm{x}=\mathbf{0 . 4 4 5} \\
\mathrm{s}=\mathbf{0 . 1 0 6} \\
\mathrm{n}=\mathbf{3 8 0}\end{array}$ & $4-X$ & -1971 & $\begin{array}{l}x=0.566 \\
s=0.124 \\
n=181\end{array}$ & $5-X-1971$ & $\begin{array}{l}\mathrm{x}=0.579 \\
\mathrm{~s}=0.125 \\
\mathrm{n}=162\end{array}$ \\
\hline $2-X I$ & -1971 & $\begin{array}{l}\mathrm{x}=0.849 \\
\mathrm{~s}=0.154 \\
\mathrm{n}=161\end{array}$ & 3-XI & -1971 & $\begin{array}{l}\mathrm{x}=0.528 \\
\mathrm{~s}=0.146 \\
\mathrm{n}=119\end{array}$ & $1-\mathrm{XI}$ & -1971 & $\begin{array}{l}x=0.638 \\
s=0.145 \\
n=153\end{array}$ & 2-XI-1971 & $\begin{array}{l}\mathrm{x}=0.653 \\
\mathrm{~s}=0.126 \\
\mathrm{n}=255\end{array}$ \\
\hline 8-XII & -1971 & $\begin{array}{l}x=0.861 \\
s=0.168 \\
n=157\end{array}$ & 5-XII & -1971 & $\begin{array}{l}\mathrm{x}=0.672 \\
\mathrm{~s}=0.168 \\
\mathrm{n}=150\end{array}$ & & & & & \\
\hline 17-I & -1972 & $\begin{array}{l}x=0.819 \\
\mathrm{~s}=0.168 \\
\mathrm{n}=163\end{array}$ & 18-I & -1972 & $\begin{array}{l}\mathrm{x}=0.686 \\
\mathrm{~s}=0.196 \\
\mathrm{n}=141\end{array}$ & 18-I & -1972 & $\begin{array}{l}x=0.783 \\
s=0.155 \\
n=156\end{array}$ & & \\
\hline 15-II & -1972 & $\begin{array}{l}x=0.790 \\
s=0.155 \\
n=146\end{array}$ & 16-II & -1972 & $\begin{array}{l}x=0.624 \\
s=0.162 \\
n=147\end{array}$ & & & & & \\
\hline 16-III & -1972 & $\begin{array}{l}x=0.761 \\
s=0.180 \\
n=134\end{array}$ & 15-III & -1972 & $\begin{array}{l}\mathrm{x}=0.827 \\
\mathrm{~s}=0.189 \\
\mathrm{n}=167\end{array}$ & & & & & \\
\hline $14-I V$ & -1972 & $\begin{array}{l}\mathrm{x}=0.800 \\
\mathrm{~s}=0.191 \\
\mathrm{n}=166\end{array}$ & $13-I V$ & -1972 & $\begin{array}{l}x=0.682 \\
s=0.244 \\
n=176\end{array}$ & 13-IV & -1972 & $\begin{array}{l}\mathrm{x}=0.582 \\
\mathrm{~s}=0.190 \\
\mathrm{n}=174\end{array}$ & 14-IV-1972 & $\begin{array}{l}\mathrm{x}=0.465 \\
\mathrm{~s}=0.171 \\
\mathrm{n}=140\end{array}$ \\
\hline $11-\mathrm{V}$ & -1972 & $\begin{array}{l}x=0.799 \\
s=0.194 \\
n=166\end{array}$ & $12-\mathrm{V}$ & -1972 & $\begin{array}{l}x=0.564 \\
s=0.177 \\
n=206\end{array}$ & & & & & \\
\hline
\end{tabular}

The composition of the catches was determined in the months in which they were large enough for statistical treatment. $\bar{x}=$ mean cephalic length in $\mathrm{mm} ; \mathrm{s}=$ standard deviation of the mean cephalic length; $n=$ number of individuals in the sample measured. 
G. chevreuxi is almost absent. At station V, however, a dense homogeneous population of small animals can be found, like at stations $\mathrm{V}$ and VI in winter.

X.1c. Composition of the migrating populations.

The pattern described in the previous section can be further analysed by means of fig. 9, table III and additional data relating to the standing crop. Unlike station $I$ in the river Slack (Dennert et al., 1969), station III in the river Dourduff is not a place where a fairly constant number of animals can complete their life cycle, but rather a place which a generation passes in the upstream and downstream direction twice a year. This explains why fig. 9 does not represent a normal yearly cycle, as does fig. 20 in the publication of Dennert et al.

From May or June the population that moved upstream in spring (from now on called "spring generation") starts migrating in the other direction. At the same time, reproduction upstream from station III is at a very low level, so an increase in the size of the upstreamers can be expected at station III.

In September and October, many juveniles migrating upstream mix with the old generation at station III. (Likewise, the very small number of downstream migrants mainly consists of these juveniles.)

In autumn adults too start migrating upstream. This results in an almost complete depopulation of the estuarine parts downstream from station II in October. From September to December at station III, and in September and October at station $\mathrm{V}$, the upstream samples contain quite a number of ovigerous females.

In November almost all animals at station VI are juveniles or small adults, so that we must conclude that fully grown adults do not migrate as far upstream as small animals. Downstream migrants at station III in November and December are exclusively adults. These animals are certainly the same individuals that migrated upstream in autumn aided by the high tides. When the period of high tides is over they immediately reverse the direction of their migrative movements.

The juveniles in the upstream reaches gradually develop into small adults. It is striking, however, that in December and January the population at station VI consists of 3 to 4 times more males than females. The same was already observed by Dennert et al. in the upstream regions of the river Slack. The explanation given by these authors, i.e. that males in fresh water attain adult morphology earlier than freshwater females, does not make sense in this situation since juveniles have already disappeared from the population in January.

At stations IV, V and VI in December and January no ovigerous females were found in the standing crop (dip net catches). However, the downstream samples in December at station VI did contain some ovigerous females and in January $10 \%$ of the downstreamers at stations $\mathrm{V}$ and VI consisted of ovigerous females. The same was found in November at station IV and in April at station V. Obviously, in areas where no salt water penetrates, or does so only in small quantities, females migrate downstream immediately after oviposition. At station III the number of females in the downstream catches rapidly increases in December and January. This possibly explains the relatively small number of females in the standing crop at station VI in these months. We assume that females generally migrate downstream at an earlier stage than males. It may be that they do not migrate as far upstream as the other sex. The standing crop at station VI in January migrates downstream to station III in the next month. Consequently, the downstream catches at station III in February contain many more males than females.

The same phenomena can be observed in the "spring generation". In March and April the downstream catches at station III contain large percentages of ovigerous females. In May the number of males increases, and in July and August the downstream samples at station III, the last of the "spring generation", show a preponderance of males.

In winter in the Dourduff a gradient in size can be observed in the standing crop between station VI and I. The smaller animals are found in the upstream reaches. Likewise, downstreamers at station $\mathrm{V}$ are significantly smaller than, or are of the same size as those at station III.

\section{X.2. Gammarus zaddachi}

\section{X.2a. Reproduction.}

Reproduction almost exclusively takes place in the estuarine parts from January till March (see fig. 11). Reproduction beyond this period is of far less importance than in G. chevreuxi. Ovigerous females have never been found upstream from station III. According to our observations, they only occur in the regions with a monthly salt penetration. 


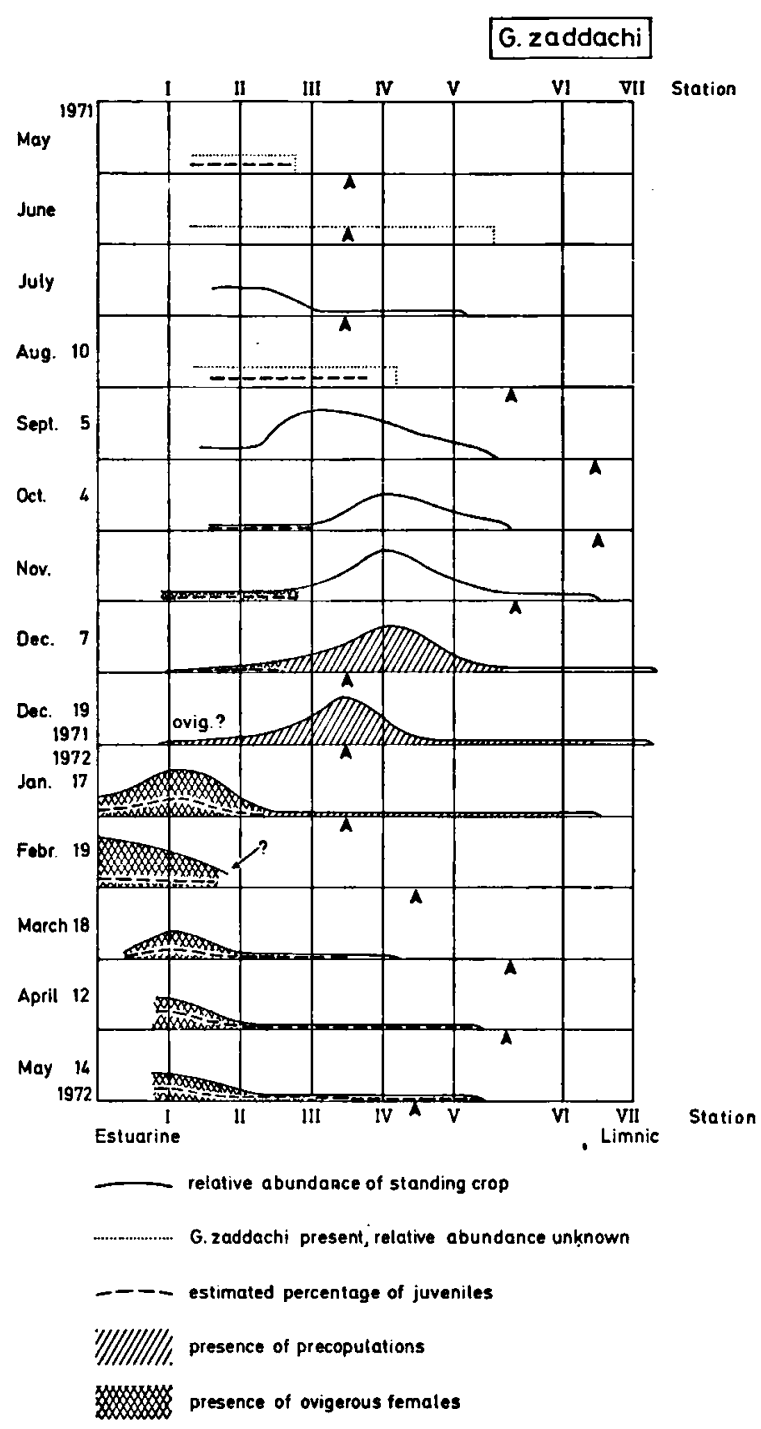

Fig. 11. The composition and estimated relative abundance of the standing crop of Gammarus zaddachi at the various stations. The composition of the standing crops of May till November 1971 is unknown in the majority of cases. For further explanation see fig. 10.

X.2b. Movement of the population in the river (see table II and fig.11).

From May till October G. zaddachi mainly lives in areas with a monthly influence of mixohaline waters. During this period a downstream migration can be observed, and the entire population penetrates further into the estuary.

Upstream migration, which starts in August at station III, takes place almost entirely in September. The first part of the population reaches station $\mathrm{V}$ during this month.

In Novèmber a downstream migration starts at stations IV and III, sharply increasing in magnitude at station III in December and at station II in January. The increased migration in Docember coincided in the year of observation with a rise in the water temperature. In January nearly the whole population of $G$. zaddachi lives in the open estuary and it is there that reproduction starts.

From March till June a small number of upstream migrating animals passes station III. At station $\mathbf{V}$ this can be observed in April only. The small upstream movements are succeeded by small downstream movements. A relatively strong downstream migration is found at stations $I$ and II only. In spring and early summer, the whole population moves further into the estuary. The total number of migrants in spring is very small as compared with that in autumn.

X.2c. Composition of the migrating population of Gammarus zaddachi at station III (see table IV).

Upstream migrants are smaller than downstreamers. The length of the downstreamers increases until December. This agrees with the fact that the whole population was born between January and April.

In August and September only, i.e. the months in which upstream migration occurs, downstreamers are smaller than in the preceding and following months. The same was found for Gammarus chevreuxi.

During the period March, April and May the downstream migrants are smaller than in December. These are mainly animals of the new generation born in the estuary, and showing a small upstream migration during these months.

Before drawing any conclusions about the migration we shall give the results of the laboratory experiments.

\section{Laboratory experiments}

\section{INTRODUCTION}

The field observations on migration and population dynamics described in the previous chapters gave rise to a number of questions. Some of these have been studied in detail in the laboratory under experimental conditions:

1. How do populations of G. zaddachi and G. chevreuxi behave in waters of various salinity/temperature conditions? The following criteria were used in these experiments: 
Table IV. The mean cephalic lengths, their standard deviations, and the mutual differences between upstream and downstream migrants of Gammarus zaddachi at station III.

\begin{tabular}{|c|c|c|c|c|}
\hline date & & $\begin{array}{l}\text { downstream } \\
\text { migrants }\end{array}$ & date & $\begin{array}{l}\text { upstream } \\
\text { migrants }\end{array}$ \\
\hline 10-VI & -1971 & $\begin{array}{l}\mathrm{x}=0.980 \\
\mathrm{~s}=0.220 \\
\mathrm{n}=28\end{array}$ & & \\
\hline 10-VII & [-1971 & $\begin{array}{l}\mathrm{x}=1.071 \\
\mathrm{~s}=0.184 \\
\mathrm{n}=11\end{array}$ & & \\
\hline 8-VII & II-1971 & $\begin{array}{l}\mathrm{x}=0.850 \\
\mathrm{~s}=\mathbf{0 . 2 3 9} \\
\mathrm{n}=7\end{array}$ & & \\
\hline 5-IX & -1971 & $\begin{array}{l}\mathbf{x}=0.983 \\
\mathrm{~s}=0.214 \\
\mathrm{n}=14\end{array}$ & 6-IX-1971 & $\begin{array}{l}\mathrm{x}=0.682 \\
\mathrm{~s}=0.186 \\
\mathrm{n}=24\end{array}$ \\
\hline $2-X I$ & -1971 & $\begin{array}{l}x=1.045 \\
s=0.166 \\
n=52\end{array}$ & & \\
\hline 8-XII & -1971 & $\begin{array}{l}\mathrm{x}=1.362 \\
\mathrm{~s}=0.232 \\
\mathrm{n}=50\end{array}$ & & \\
\hline 16-III & -1972 & $\begin{array}{l}\mathrm{x}=1.005 \\
\mathrm{~s}=0.244 \\
\mathbf{n}=12\end{array}$ & & \\
\hline 14-IV & -1972 & $\begin{array}{l}\mathbf{x}=1.055 \\
\mathrm{~s}=0.168 \\
\mathrm{n}=5\end{array}$ & & \\
\hline $11-V$ & -1972 & $\begin{array}{l}x=0.915 \\
s=0.166 \\
n=14\end{array}$ & $12-V-1972$ & $\begin{array}{l}x=0.670 \\
s=0.225 \\
n=28\end{array}$ \\
\hline \multicolumn{5}{|c|}{$\begin{array}{l}\text { downstream migrants: } \\
\text { 8-XII-1971 }>>\text { all other measured downstream samples } \\
2-\mathrm{XI}-1971>>11-\mathrm{V}-1972\end{array}$} \\
\hline \multicolumn{2}{|c|}{$\begin{array}{r}\text { 10-VII-1971 } \\
2-X I \quad-1971\end{array}$} & 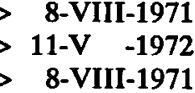 & & \\
\hline
\end{tabular}

downstreamers 5-IX-1971 > > upstreamers 6-IX-1971 downstreamers $11-\mathrm{V}-1972>>$ upstreamers $12-\mathrm{V}-1972$

$>>=$ the cephalic lengths of the two samples differ statistically according to the $t$ test, $99 \%$ significance; $>=$ the cephalic lengths of the two samples compared differ statistically according to the $t$ test, $95 \%$ significance. For further explanation see table III.

a) survival rate

b) reproduction rate, i.e. the numbers of precopulations and ovigerous females in a given population and the presence or absence of juveniles.

2. How do populations of both species behave in shock-biotope conditions, i.e. limnic conditions periodically alternating with conditions with higher salınities? Both mortality rate and reproduction rate were used as criteria.

3. Are there any differences in salinity tolerance between adults and juveniles? The survival rate was used as a criterion in these experiments.

\section{ANIMALS USED IN THE EXPERI- MENTS}

It is well known from the literature that Gammarus zaddachi is a difficult species to keep alive in the laboratory (Kinne, 1960; Sutcliffe, 1968; Bulnheim, 1972). In this context, it is worth noting that Gammarus zaddachi in nature has never been found in small, stagnant, fresh or brackish bodies of water (Spooner, 1947; Salmon, 1959; den Hartog, 1964). In the laboratory the animals were usually kept in small storage basins, a situation completely different from their natural habitat. This may possibly cause a shift in the tolerance of temperature and salinity between experimental and natural conditions.

In the literature $G$. chevreuxi is known as an animal that can easily be kept and reared in the laboratory for experimental use (e.g. Sexton, 1924). We must keep in mind these differences in behaviour between the two species under laboratory conditions in considering the results of the experiments.

The physiological reaction of aquatic animals to various salinity/temperature conditions can vary from summer to winter (Dehnel, 1962; Todd, 1963). All our experiments were therefore started at the same season.

Since physiological behaviour can also change during the development of these animals, as described by Verwey (1966) and Dennert et al. (1969) for Gammarus zaddachi, the experiments with any of the two species were performed with animals of about the same age. Accordingly, the experiments with $G$. chevreuxi were started with animals caught at station VI in winter when a homogeneous population of small adults can be found here (see section X.1b). The experiments with G. zaddachi were performed with adults from precopulations caught at station $I$ in the same period.

Males and females were separated and kept apart for 10 or 12 days to ensure that no oviposition could have taken place in any of the females before the experiments were started.

\section{METHODS}

The animals were kept in water of $8^{\circ} \mathrm{C}$ and $1000 \mathrm{mg} \mathrm{Cl} / \mathrm{l}$. From this medium they were trans- 
ferred to the various experimental conditions without any pre-adaptation.

The size of the experimental basins was $20 \times$. $20 \times 9 \mathrm{~cm}$. Constant aeration created some minor water currents.

Temperature changes in the experimental basins were less than $0.5^{\circ} \mathrm{C}$.

The fresh water used in the experiments originated from the limnic parts of the river Dourduff. The various mixohaline media used in the experiments were made by mixing the same Dourduff water with marine water from the Dutch coast.

Distilled water was added at regular intervals to compensate for evaporation. The $\mathrm{Cl}$ and $\mathrm{Ca}$ content were checked 3 to 4 times every month, the $\mathrm{Na}$ content only incidentally. Changes in chlorinity never exceeded $5 \%$.

The $\mathrm{pH}$ in the river water varied from 7.2 to 8.0. In water of $800 \mathrm{mg} \mathrm{Cl} / 1$ and $8000 \mathrm{mg} \mathrm{Cl} / 1$ the $\mathrm{pH}$ was more stable, varying from 7.7 to 8.0 and 8.0 to 8.2 , respectively.

Organic pollution, bacterial and algal growth were controlled by constant aeration and periodical changing of the water, especially of the water in basins at higher temperatures.

For practical reasons only pebbles were used as a substrate. Fine gravel, in which $G$. chevreuxi is often found in nature, could possibly have damaged the animals when checking them.

The animals were fed exclusively with Stellaria media Vill., a plant which they consume almost completely and therefore leaves no remains as a source for pollution.

During the experiments a light period of $14 \mathrm{~h}$ was alternated with a dark period of $10 \mathrm{~h}$.

The population density was always kept far below the values found in the field.

At regular intervals number of surviving animals, precopulations and ovigerous females were counted and the hatching of juveniles was noted.

Unless otherwise stated, all experiments were carried out in duplicate. In the figures illustrating the results concerning survival rates the number of animals plotted on the y-axis is the sum of the number of animals in the duplicate basins.

Statistical advice was given by $R$. Potharst of the Mathematisch Centrum, Amsterdam. The problem consists in finding a model in which the survival rates under different experimental conditions can be compared. As a logistic model is meeting difficulties (see Dennert, 1974), a linear (stochastic) model was used, in which mean "length of life" can be compared for the different experimental conditions. "Length of life" is defined as the num- ber of days between the start of the experiment and the death of an animal in the experiment. As there was no daily check, an animal is supposed to have died in the middle of the period between the check at which his death is certified and the previous check. For animals, still alive at the end of the experiment, the length of life is defined as the number of days of the experiment plus two. When we analyse for one species the variation in length of life under different experimental conditions, we have to take into account that this variation may be blurred by differences in length of life between the populations in the basins with the same experimental condition (duplicate basins). That is why we look for a model in which this "effect of the basins" can be removed after estimating it separately, thus allowing us to test the differences in length of life caused by the various experimental conditions.

Technically speaking this means a two factor hierarchic analysis of variance, in which the second factor (effect of the basins) is nested in the first (effect of experimental conditions). For the theory of this approach see Dennert, 1974. With a standard $F$ test it is checked whether there is a significant effect of both factors on length of life ( $\alpha=$ 0.05 ). Finally the influence on mean length of life of all environments can be compared by testing them two by two using the Scheffé multiple comparison technique with $\alpha=0.05$. As a result of these tests the whole series of conditions can be arranged in groups; the experimental conditions within such a group do not show differences in their effect on mean length of life. The results of this statistical approach are discussed in sections XIV.4 and XV.4.

\section{Results}

\section{GAMMARUS CHEVREUXI}

XIV.1. Survival rate and reproduction at various temperature/salinity combinations

A series of experiments was started with the following salinity/temperature combinations:

- Water from the river Dourduff, i.e. $40 \mathrm{mg} \mathrm{Cl} / \mathrm{l}$; $25 \mathrm{mg} \mathrm{Na} / 1 ; 15-20 \mathrm{mg} \mathrm{Ca} / 1$ and a low but varying $\mathrm{Mg}$ content at $14^{\circ}, 9^{\circ}$, and $5^{\circ} \mathrm{C}$.

- Mixohaline water of $800 \mathrm{mg} \mathrm{Cl} / 1 ; 500 \mathrm{mg} \mathrm{Na} / 1$; 80-150 $\mathrm{mg} \mathrm{Ca} / 1$ at $14^{\circ}, 9^{\circ}$, and $5^{\circ} \mathrm{C}$.

- Mixohaline water of $8000 \mathrm{mg} \mathrm{Cl} / 1 ; 4500 \mathrm{mg}$ $\mathrm{Na} / \mathrm{l} ; 200$ to $300 \mathrm{mg} \mathrm{Ca} / 1$ at $14^{\circ}, 9^{\circ}$, and $5^{\circ} \mathrm{C}$. 

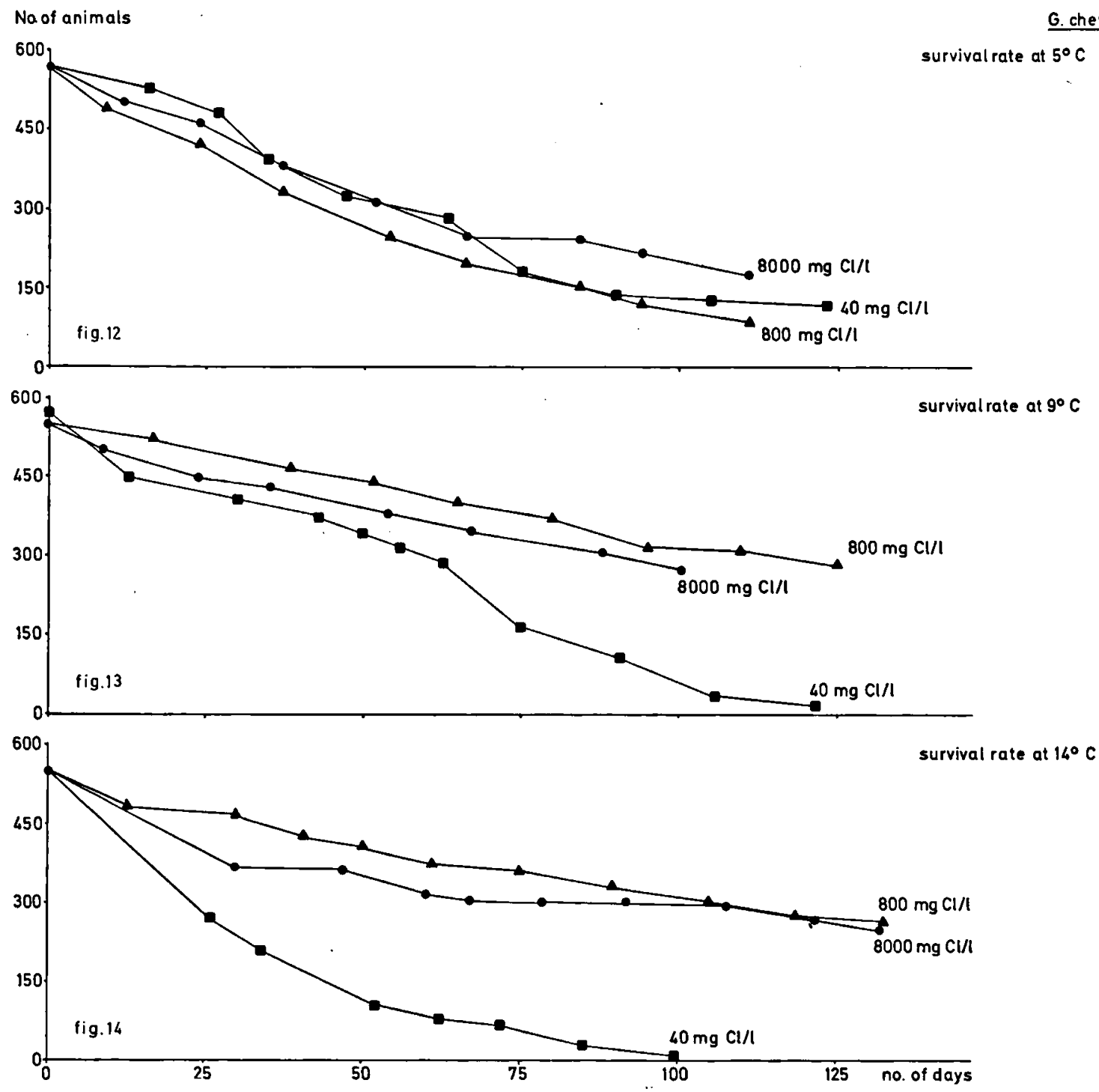

Figs. 12, 13 and 14. The survival rate of adults of Gammarus chevreuxi at three salinities, and at $5^{\circ}, 9^{\circ}$ and $14^{\circ} \mathrm{C}$, respectively.

The initial number of animals placed per experimental basin $(20 \times 20 \mathrm{~cm})$ was 275 .

XIV.1a. Survival rate.

The results of the experiments under the various conditions are illustrated in figs. 12-17. In these graphs the following features are striking:

- The survival rate is low at $5^{\circ} \mathrm{C}$ at all salinities and the differences between the three salinities are fairly small (fig. 12). Under mixohaline conditions, the survival rate increases considerably at higher temperatures (figs. 16 and 17). Under limnic conditions, survival rates decrease with increasing temperatures.
- Under limnic conditions survival is low at all temperatures, especially at $14^{\circ} \mathrm{C}$ (fig. 15). At $9^{\circ}$ and $14^{\circ} \mathrm{C}$, unlike the situation at $5^{\circ} \mathrm{C}$, a rise in salinity to $800 \mathrm{mg} \mathrm{Cl} / \mathrm{l}$ causes a considerable rise in survival rate. A further rise to $8000 \mathrm{mg} \mathrm{Cl} / 1$ has no significant effect (see figs. 12,13 and 14).

Conclusions: A temperature of $5^{\circ} \mathrm{C}$ as well as (limnic) river water form marginal conditions for Gammarus chevreuxi.

XIV.1b. Reproduction.

The sex ratio could not be determined in all the basins. It is therefore only possible to compare the reproduction rates at the various salinity/tempera- 


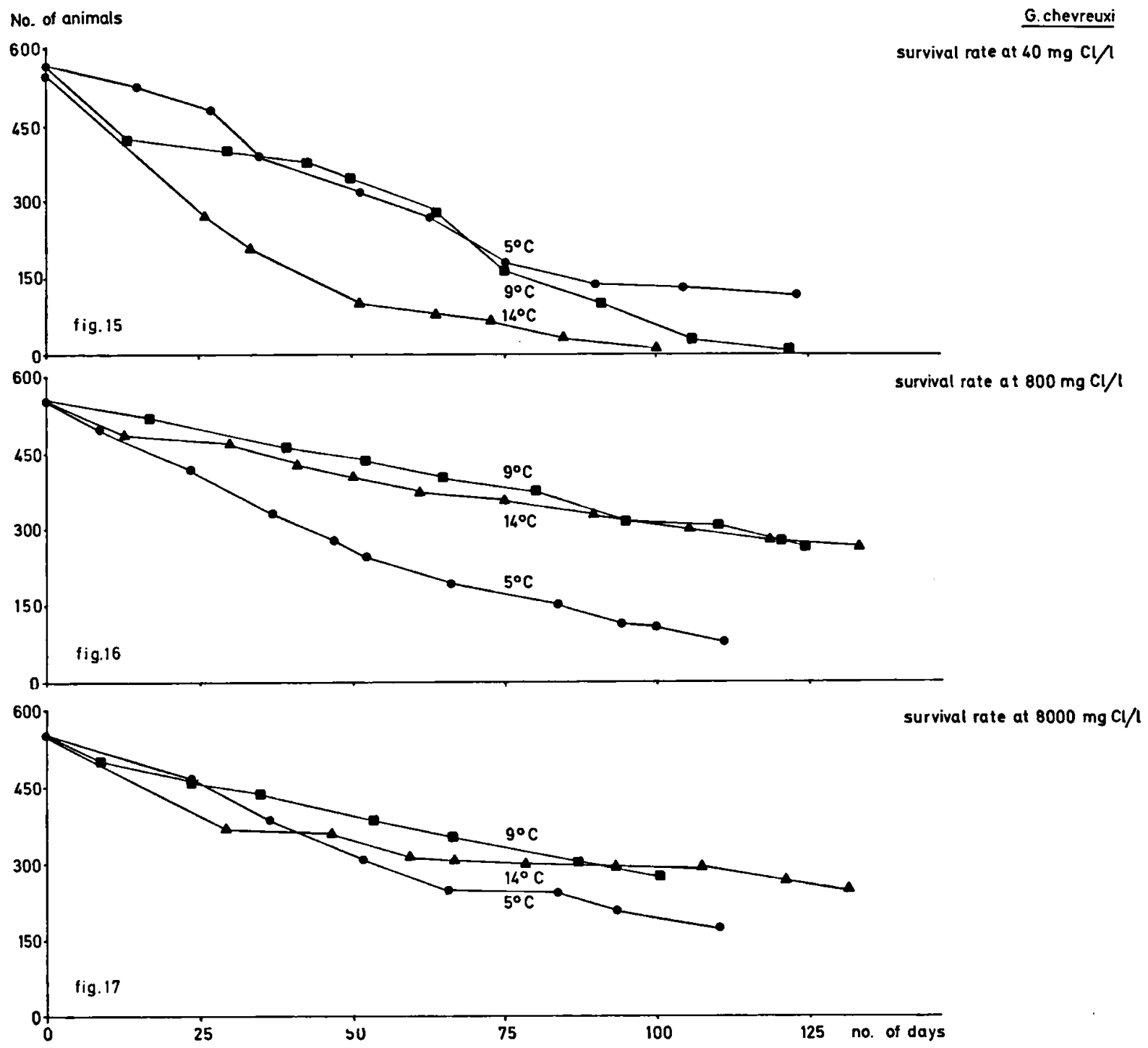

Figs. 15, 16 and 17. The survival rate of adults of Gammarus chevreuxi at three temperatures in waters with 40,800 and $8000 \mathrm{mg} \mathrm{Cl} / \mathrm{l}$, respectively.

ture combinations with certain limitations. The results are as follows:

- Ovigerous females were never found in river water at $14^{\circ}$ and $9^{\circ} \mathrm{C}$.

- Ovigerous females were found at all three temperatures in water of 800 and $8000 \mathrm{mg} \mathrm{Cl} / \mathrm{l}$. Although there were differences in the number of ovigerous females in the various salinity/temperature combinations tested, no general line could be observed.

- No juveniles could be found at $5^{\circ} \mathrm{C}$, although at this temperature many ovigerous females were observed both in waters of 800 and $8000 \mathrm{mg} \mathrm{Cl} / 1$. Most probably the juveniles never hatch at this temperature although the passibility remains that they die soon after hatching or are eaten by the adults.

- Many juveniles could be observed at $9^{\circ}$ and $14^{\circ} \mathrm{C}$ in waters of 800 and $8000 \mathrm{mg} \mathrm{Cl} / 1$.

XIV.2. The influence of low salinities and a periodical rise in salinity on survival and reproduction

In this series of experiments we tried to find answers to the following questions:

What is the lowest salinity at which reproduction can take place?

What is the effect on survival and reproduction when animals which normally live under limnic 
conditions are periodically transferred to higher salinities?

All the experiments were carried out at $10.5^{\circ} \mathrm{C}$, a temperature that was assumed to be close to the optimum temperature for the animals on the basis of the results of the previous experiments (see section XIV.1). The chlorinities used in the various experiments were $40,150,400,1000$, and 12,000 $\mathrm{mg} / \mathrm{l}$.

In some experiments we tried to simulate a "shock biotope" by transferring animals accustomed to living in river water to a chlorinity of $1000 \mathrm{mg} / \mathrm{l}$ once or twice a week for 24 hours. During the last few weeks of the experiments the animals were transferred to water of 10,000 instead of $1000 \mathrm{mg} \mathrm{Cl} / \mathrm{l}$. The animals were transferred from one medium to another without any adaptation. Before being transferred from a higher salinity to a lower one, they were always quickly rinsed in distilled water. The animals were transferred from one medium to another by catching them in a sieve. This method was also used for making a weekly count of the other animals.

In these series the ovigerous females stay and hatch in the original basins. So the same ovigerous females can be observed in several counts. In fig. 19 , illustrating the number of ovigerous females at the various chlorinities, the cumulative number of ovigerous females is plotted. Each value is the sum of the number of ovigerous females in the actual count and the number of ovigerous females in all preceding counts. Since this series of experiments was done at one temperature only $\left(10.5^{\circ} \mathrm{C}\right)$ this method gives a possibility to compare the number of females that reproduce at the various chlorinities, for the development of the eggs is mainly dependent of temperature and far less of salinity (cf. Kinne, 1953).

The initial number of animals per aquarium was 150; the sex ratio was not checked.

\section{XIV.2a. Survival rate.}

The survival rate at the various chlorinities is shown in fig. 18 .

- No differences could be found between survival rates in waters with 1000 and $12,000 \mathrm{mg} \mathrm{Cl} / 1$.

- At chlorinities lower than $1000 \mathrm{mg} / \mathrm{l}$, the survival rate decreased with chlorinity. A constant chlorinity of $150 \mathrm{mg} / \mathrm{l}$ or lower led to complete extinction of the population within a few months.

- A periodical rise in chlorinity has a considerable effect upon the survival rate in populations that normally live under limnic conditions. Initially a higher mortality than in constant limnic conditions was observed. After a month, however, mortality decreased and the population remained at an almost constant level till the end of the experiments. (It seems that the first sudden changes in salinity select a part of the population.)

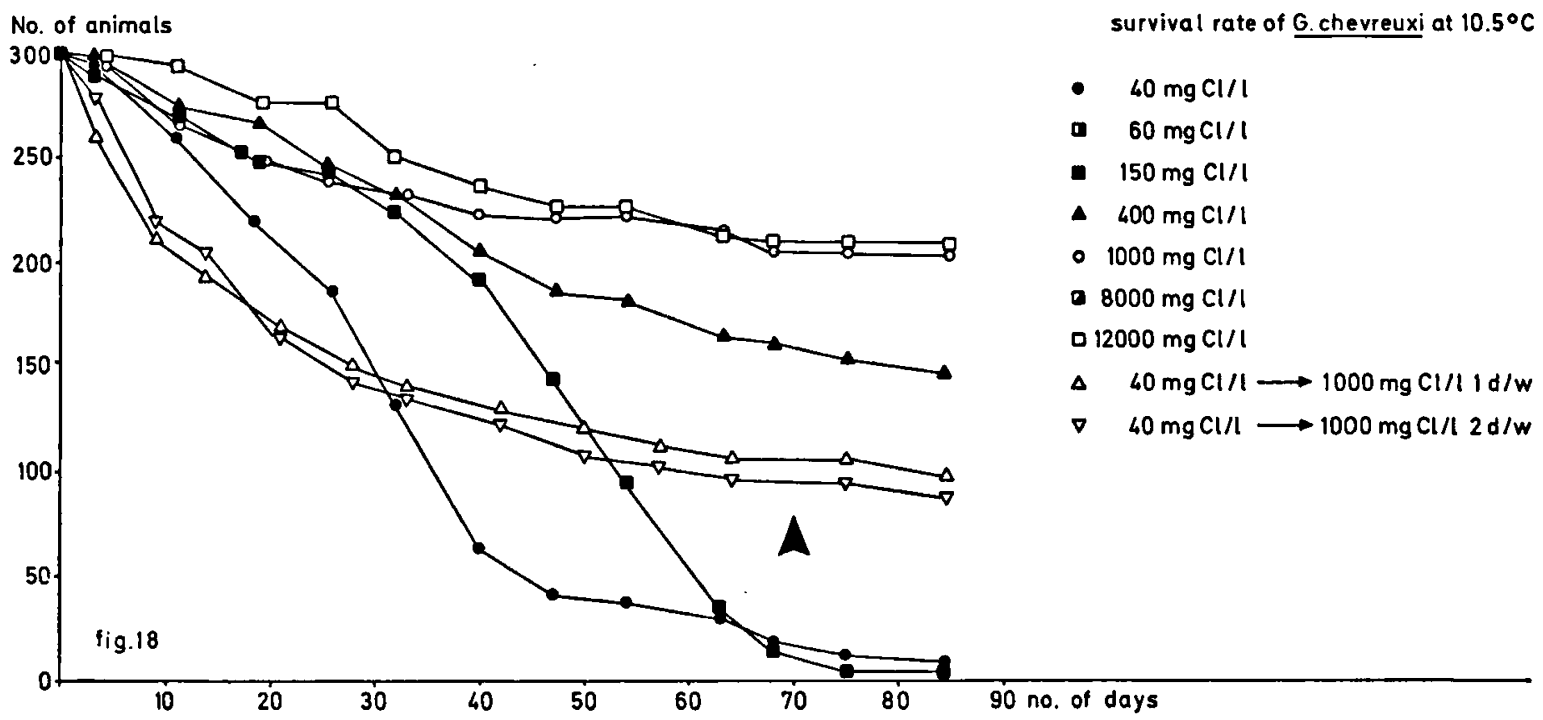

Fig. 18. The survival rate of adults of Gammarus chevreuxi at $10.5^{\circ} \mathrm{C}$ in waters of various constant chlorinities and in waters with periodically fluctuating chlorinities. $40 \mathrm{mg} \mathrm{Cl} / 1 \rightarrow 1000 \mathrm{mg} \mathrm{Cl} / 11 \mathrm{~d} / \mathrm{w}$ means: animals accustomed to live in water of $40 \mathrm{mg} \mathrm{Cl} / 1$ are transferred to water of $1000 \mathrm{mg} \mathrm{Cl} / 1$ once a week for one day. The arrow indicates the day after which the animals are transferred to water of 10,000 instead of $1000 \mathrm{mg} \mathrm{Cl} / /$. 
XIV.2b. Reproduction.

The number of ovigerous females is illustrated in fig. 19.

- Only fairly small differences in reproduction rate could be observed between animals kept at chlorinities of 1000 and $12,000 \mathrm{mg} / 1$.

- At lower salinities no reproduction of any importance could be found. Juveniles developed in chlorinities higher than $400 \mathrm{mg} / \mathrm{l}$. Offspring increased with chlorinity.

- In populations periodically transferred to chlorinities of $1000 \mathrm{mg} / \mathrm{l}$ a somewhat higher number of ovigerous females could be observed. Juveniles were only found in the basins with the highest salinity. Transferring these populations to a chlorinity of $10,000 \mathrm{mg} / 1$ resulted in a sharp increase in the total number of ovigerous females.

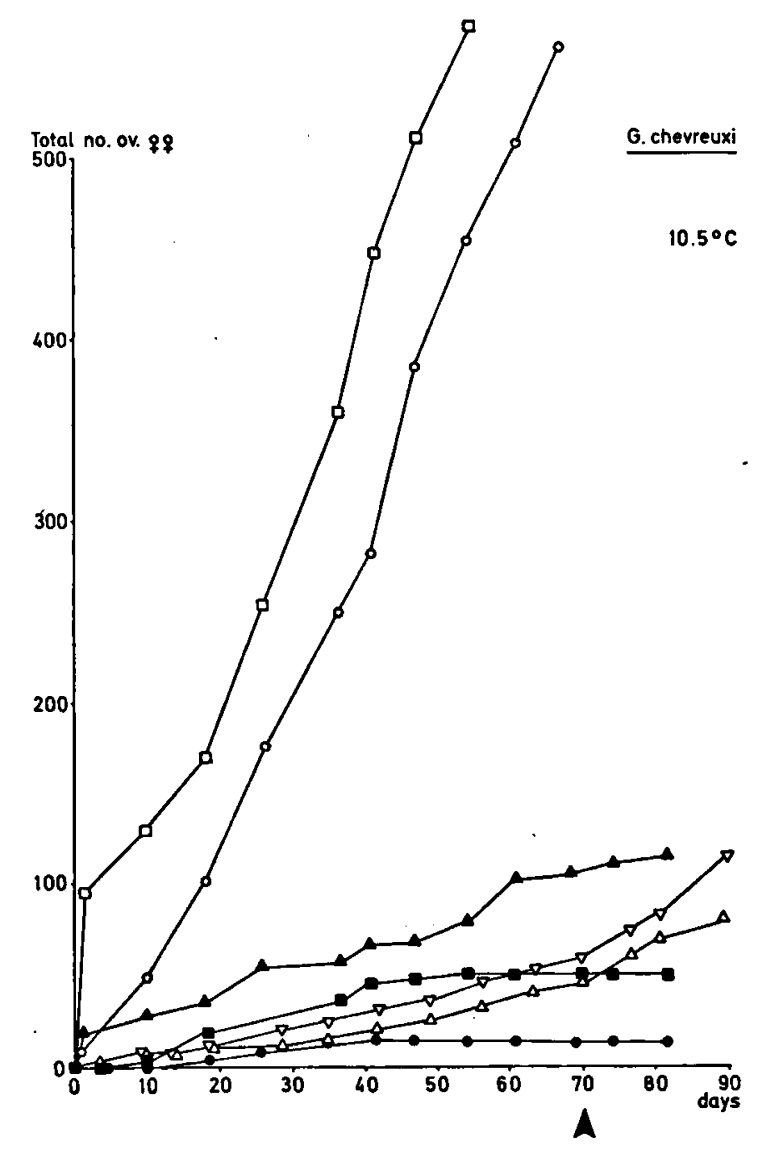

Fig. 19. The number of ovigerous females of Gammarus chevreuxi at $10.5^{\circ} \mathrm{C}$ in waters of various chlorinities and in water of low chlorinity with a periodical rise in chlorinity. The number of ovigerous females plotted in this figure is the cumulative number of ovigerous females. Each value is the sum of the number of ovigerous females in the actual count and the number of ovigerous females in all preceding counts (see section XIV.2). For further explanation see fig. 18.
Conclusions:

The results from sections XIV.1b and XIV.2b can be summarized as follows.

At chlorinities lower than $400 \mathrm{mg} / \mathrm{l}$, ovigerous females can hardly ever be observed. Juveniles were never found either at these salinities, or at $5^{\circ} \mathrm{C}$. At $400 \mathrm{mg} \mathrm{Cl} / 1$ quite a number of females produce eggs (up to 10 or $20 \%$ of the population) and even an offspring. At chlorinities above 400 $\mathrm{mg} / \mathrm{l}$ the majority of females are constantly ovigerous and the number of juveniles is many times higher than at $400 \mathrm{mg} / 1$.

In populations living under limnic conditions a periodical rise in chlorinity to $10,000 \mathrm{mg} / 1$ causes a sharp increase in egg production.

\section{XIV.3. Survival of juveniles at low salinities}

Since juveniles and adults do not always inhabit the same part of the salinity range in the Dourduff (see section XIV.lb) some experiments were carried out to obtain an answer to the following questions: Can juveniles develop under limnic conditions, and what is the survival rate under these conditions as compared with that at higher salinities?

What is the survival rate of juveniles as compared with that of adults under limnic conditions?

Methods: three- to five-day old juveniles, originating from water with a chlorinity of $1000 \mathrm{mg} / \mathrm{l}$ and a temperature of $10.5^{\circ} \mathrm{C}$ were transferred to chlorinities of 60,400 , and $8000 \mathrm{mg} / \mathrm{l}$. The temperature was kept at $10.5^{\circ} \mathrm{C}$. The initial number of juveniles in each aquarium was 100.

Results: the survival rates at the various chlorinities are illustrated in fig. 20. Fig. 18 can be used to compare these results with those found for adults, since the juveniles used in these experiments were produced by females from the same stock as used in fig. 18. The following information can be derived from these figures:

- The mortality of juveniles in all cases is as high as in adults. The salinity effect seems to be identical to that observed in adults.

- At a chlorinity of $60 \mathrm{mg} / 1$ mortality decreases sharply after about one month; $75 \%$ of the juveniles which survived the first month also survive in the second month. For adults the situation is quite different (fig. 18), almost $100 \%$ of the animals in chlorinities of 40 and $150 \mathrm{mg} / \mathrm{l}$ dying after two months.

Remarks: In these experiments the survival rates of very young juveniles were compared with those 


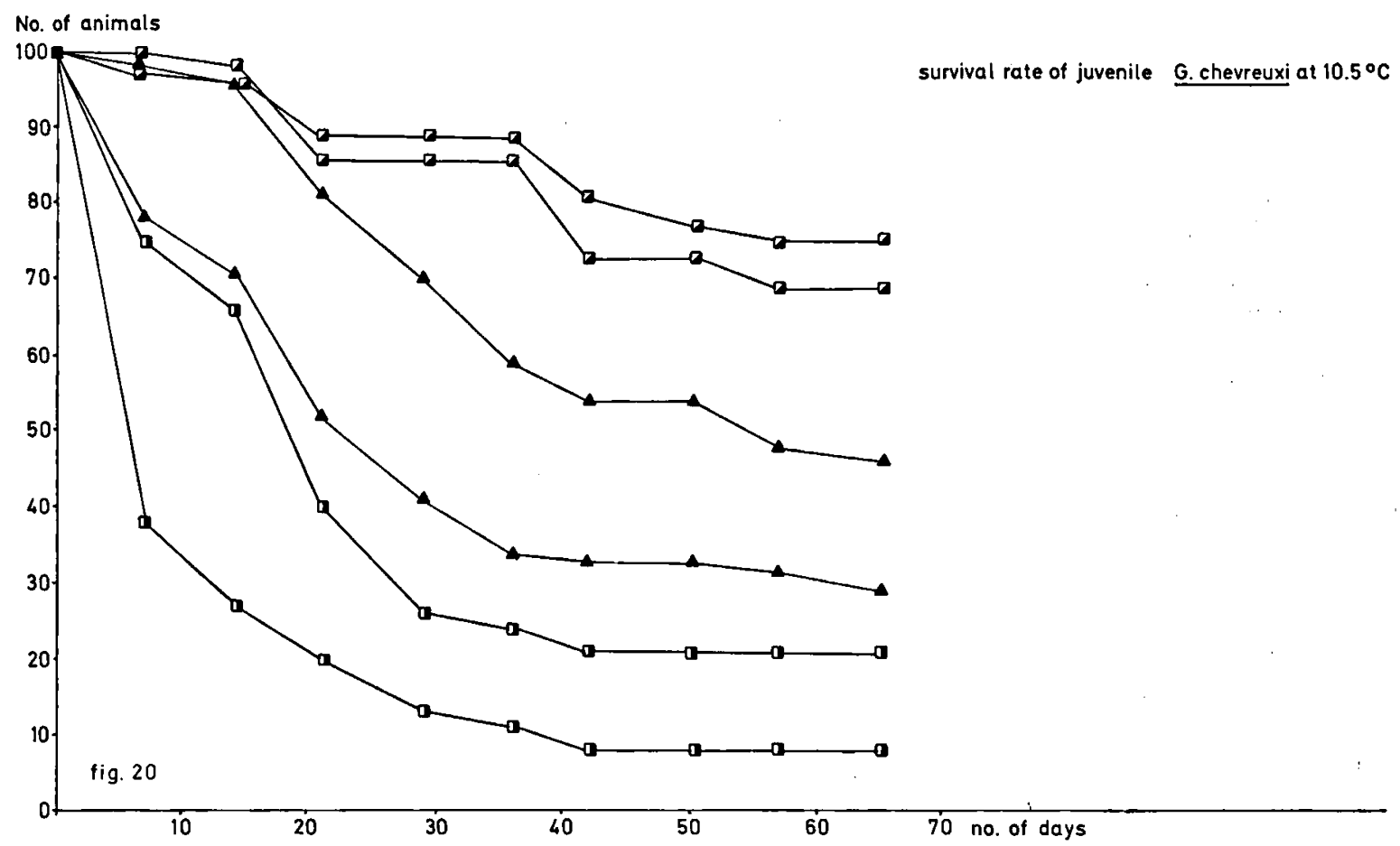

Fig. 20. The survival rate of juveniles of Gammarus chevreuxi in waters with various chlorinities at a temperature of $10.5^{\circ} \mathrm{C}$. The results of the duplicate experiments are given separately. For further explanation see fig. 18.

Adults of Gammarus chevreuxi

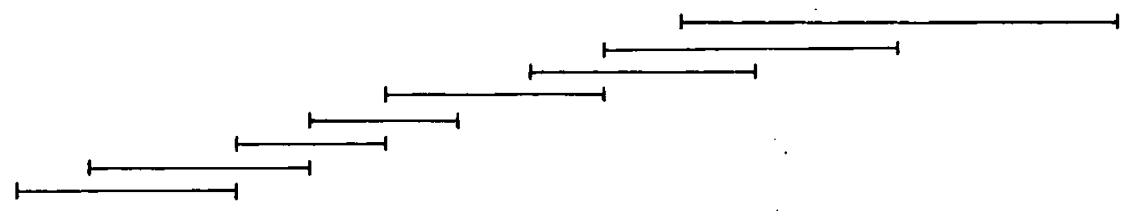

$\begin{array}{cccccccccccccccccc}14 & 10.5 & 10.5 & 10.5 & 10.5 & 5 & 9 & 5 & 5 & 14 & 10.5 & 9 & 10.5 & 14 & 10.5 & 9 & { }^{\circ} \mathrm{C} & \\ 80 & 40 & W_{1} & W_{2} & 150 & 800 & 80 & 80 & 8000 & 8000 & 400 & 8000 & 12000 & 800 & 1000 & 800 & \mathrm{mg} \mathrm{Cl} / 1 & \\ 31.0 & 32.1 & 38.6 & 39.8 & 43.2 & 49.5 & 51.0 & 53.2 & 56.5 & 58.3 & 59.3 & 64.2 & 66.1 & 66.5 & 69.0 & 70.2 \text { mean length of life }\end{array}$

Juveniles of Gammarus chevreuxi

$\begin{array}{llrl}10.5 & 10.5 & 10.5 & \circ \\ 40 & 400 & 8000 \mathrm{mg} \mathrm{Cl} \\ 19.5 & 39.2 & 58.0 & \text { mean length of life }\end{array}$

(in Jays)

Fig. 21. Comparison of the various temperature/chlorinity combinations concerning their effects on the mean length of life of Gammarus chevreuxi using statistical analysis as explained in section XIII. The temperature/chlorinity combinations used in the laboratory experiments together with the mean length of life found at the various combinations are ranged in order of increasing mean length of life. Combinations overlapped by the same horizontal line caused no significant differences in mean length of life. W1 and W2 = animals adapted to live in water of $40 \mathrm{mg}$ $\mathrm{Cl} / \mathrm{l}$ transferred to water of $1000 \mathrm{mg} \mathrm{Cl} / 1$ once or twice a week for one day, respectively. 
of young adults from limnic areas, i.e. animals that can maintain themselves at a lower salinity. In view of the distribution in their natural habitat it would be better to know whether old juveniles and preadults have a higher tolerance of limnic conditions than adults, i.e. a situation somewhat comparable to the situation at the end of the experiment. The results of our experiment do not exclude a positive answer to this question.

\section{XIV.4. Statistical significance of the results}

The differences in length of life between the populations in the basins with the same experimental condition, as well as the differences between the populations kept at different experimental conditions are highly significant. So the use of a two factor hierarchic analysis of variance made sense.

From fig. 21 it can be derived which temperature/chlorinity combinations cause significantly different effects on mean length of life. At first sight it looks remarkable that in the basins with periodically changing salinities the mean length of life of adults does not differ statistically from that in basins with the unfavourable combination of low salinity and high temperature, since at the end of the experiments with periodically changing salinities still $30 \%$ of the animals is alive, whereas in the basins with high temperature and low salinity all the animals died within two months. Of course, we should keep in mind that in the periodically changing conditions the initial mortality is rather high, thus diminishing the mean length of life considerably. Prolongation of the experiments probably would have resulted in statistical differences.

In the experiments with juveniles each experimental condition had a different effect on mean length of life.

\section{GAMMARUS ZADDACHI}

XV.1. Survival and reproduction at various salinity/temperature combinations

The same experiments were performed with this species as with $G$. chevreuxi. The animals were placed in water with chlorinities of 80,800 and $8000 \mathrm{mg} / 1$ at $5^{\circ}, 9^{\circ}$ and $14^{\circ} \mathrm{C}$. It was impossible to perform these experiments in duplicate for lack of facilities. The initial number of animals in each aquarium was 50; the sex ratio was always 1 .

In this series ovigerous females were kept isolated. Immediately after hatching they were replaced in the original basins. So we can define the number of times that females reproduced under the various conditions.

\section{XV.1a. Survival rate.}

From figs. 22, 23 and 24, showing the survival rate of $G$. zaddachi under the various experimental conditions, we can derive the following information:

- The highest survival values are found at $5^{\circ} \mathrm{C}$; differences between the various salinities are small. Increasing temperatures cause higher mortality rates. This temperature effect is more conspicuous at lower salinities; low salinities can be tolerated at low temperatures only.

Conclusion: of the temperatures and salinities used in these experiments, $5^{\circ} \mathrm{C}$ and $8000 \mathrm{mg} \mathrm{Cl} / 1$ are the most favourable for $G$. zaddachi.

- In general, the survival rate of $G$. zaddachi is lower than that of $G$. chevreuxi. At optimum conditions, $G$. chevreuxi shows a mortality of $50 \%$ in about 150 days; the population of $G$. zaddachi is already reduced to $50 \%$ in 70 to 80 days. However, this was to be expected, since G. zaddachi is difficult to keep under laboratory conditions (cf. section XII). It should be borne in mind also that differences in age between the two species (the chevreuxi population was younger than that of G. zaddachi, see section XII) may have influenced the results.

\section{XV.1b. Reproduction.}

The number of ovigerous females in each basin, starting with $25 \sigma^{\circ} \sigma^{\circ}$ and $25 \% \%$, is given in fig. 25.

- At chlorinities of 80 and $800 \mathrm{mg} / 1$ no ovigerous females were found at $14^{\circ} \mathrm{C}$. At lower temperatures, oviposition takes place. At $5^{\circ} \mathrm{C}$ a higher number of females produces eggs than at $9^{\circ} \mathrm{C}$. The number of ovigerous females at $80 \mathrm{mg} / 1$ is usually smaller than at $800 \mathrm{mg} / \mathrm{l}$.

- At $8000 \mathrm{mg} \mathrm{Cl} / 1$ ovigerous females can be found at the two temperatures investigated, e.g. $5^{\circ}$ and $14^{\circ} \mathrm{C}$. (The experiment at $9^{\circ} \mathrm{C}$ failed because of technical problems.) The number of females producing eggs at $5^{\circ} \mathrm{C}$ is only slightly different (even smaller) from that at $14^{\circ} \mathrm{C}$.

- Consequently, we can say that of the conditions investigated in these experiments the highest chlorinity and the lowest temperature are the most favourable condition for egg production. It is only at the favourable chlorinity of $8000 \mathrm{mg} / \mathrm{l}$ that the temperature effect is negligible.

- At a chlorinity of $80 \mathrm{mg} / 1$ juveniles were never found. The reason for this is so far unknown (see also section XV.2b). 

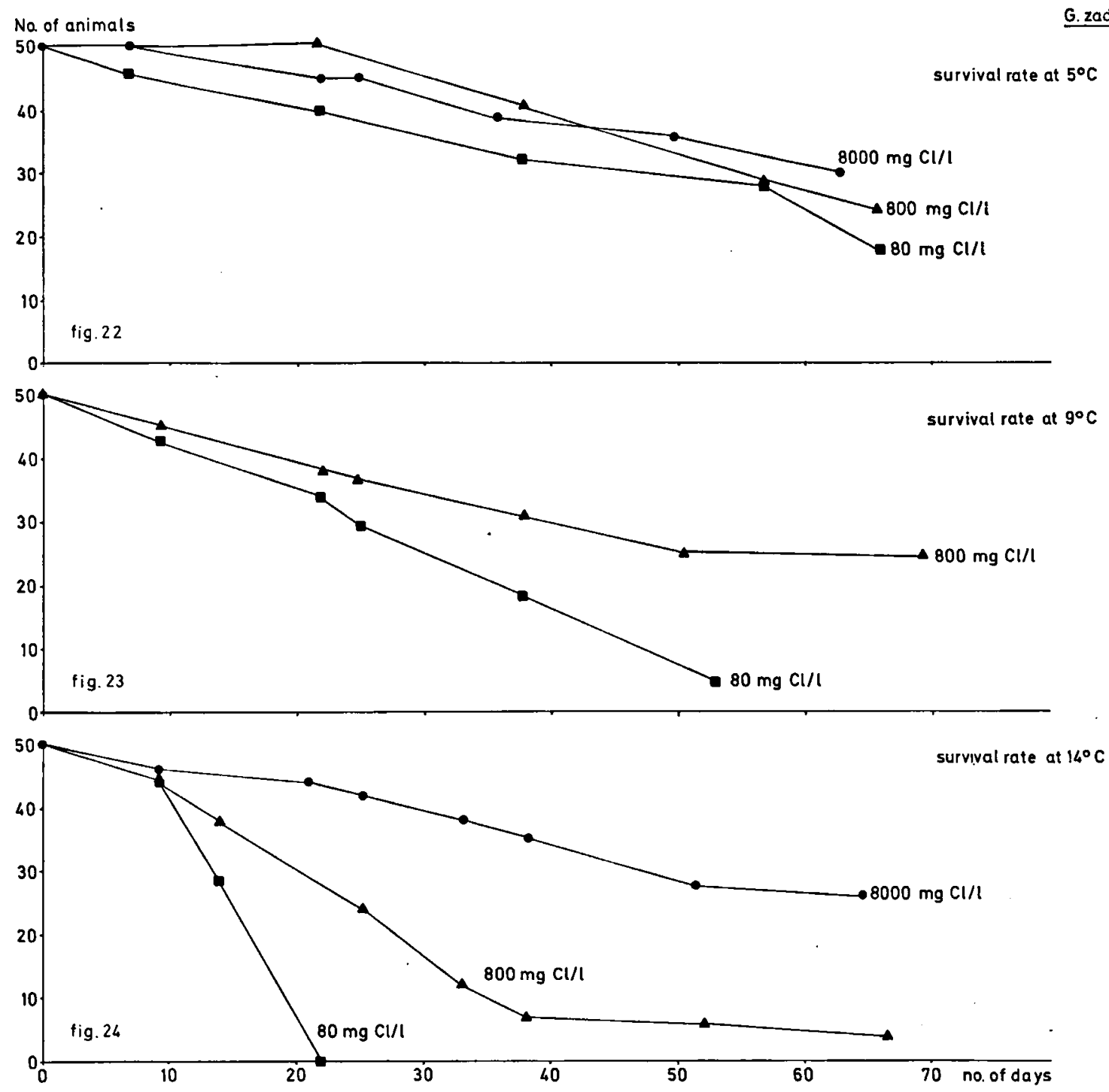

Figs. 22, 23 and 24. The survival rate of adults of Gammarus zaddachi at three chlorinities, at $5^{\circ}, 9^{\circ}$ and $14^{\circ} \mathrm{C}$, respectively.

XV.2. The influence of low salinities and periodical salinity changes on survival and reproduction

In this series of experiments we tried to find out if $G$. zaddachi could complete its reproductive cycle under constant limnic conditions at $6.5^{\circ} \mathrm{C}$, i.e. a temperature at which reproduction had been observed in the limnic parts of the river Slack by Dennert et al., 1969.

We also studied the influence of periodical rises in salinity upon the reproduction and survival rate of animals accustomed to living in fresh water. (Because of the low temperature, differences in mortality are expected to be of minor importance in these experiments (see fig. 22)).
The following ion concentrations were used: 70 $\mathrm{mg} \mathrm{Cl} / 1$ and $35 \mathrm{mg} \mathrm{Ca} / 1 ; 1000 \mathrm{mg} \mathrm{Cl} / 1$ and 150 $\mathrm{mg} \mathrm{Ca} / \mathrm{l} ; 70 \mathrm{mg} \mathrm{Cl} / 1$ with a rise to $1000 \mathrm{mg} \mathrm{Cl} / 1$ once a week for $24 \mathrm{~h} ; 70 \mathrm{mg} \mathrm{Cl} / 1$ with a rise to $1000 \mathrm{mg} \mathrm{Cl} / 1$ twice a week for $24 \mathrm{~h} ; 70 \mathrm{mg} \mathrm{Cl} / 1$ with a rise to $12,000 \mathrm{mg} \mathrm{Cl} / 1(\mathrm{Ca} 350 \mathrm{mg} / \mathrm{l})$ twice a week for $24 \mathrm{~h}$.

Each aquarium contained an initial number of 50 animals; the sex ratio was $1: 1$.

XV.2a. Survival rate.

A series of experiments in duplicate was carried out to determine the survival rate of adults of $G$. zaddachi. The results of this series of experiments (called series 1) are treated in section XV.4. 


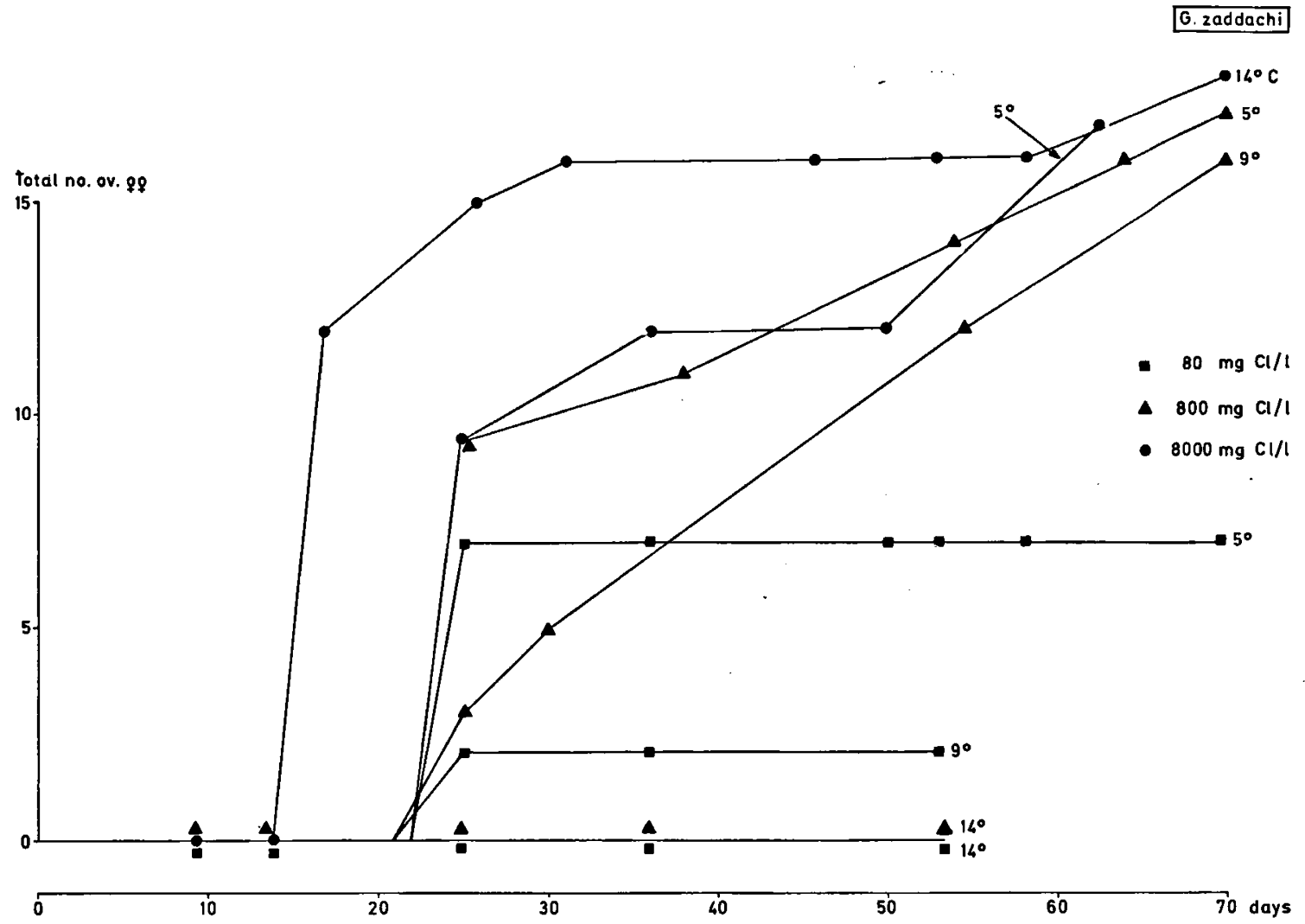

Fig. 25. The number of ovigerous females of Gammarus zaddachi under various temperature/chlorinity conditions. The number of ovigerous females plotted in the figure is the cumulative number of times that females have reproduced. Each value is the total number of times that females have reproduced in the preceding period.

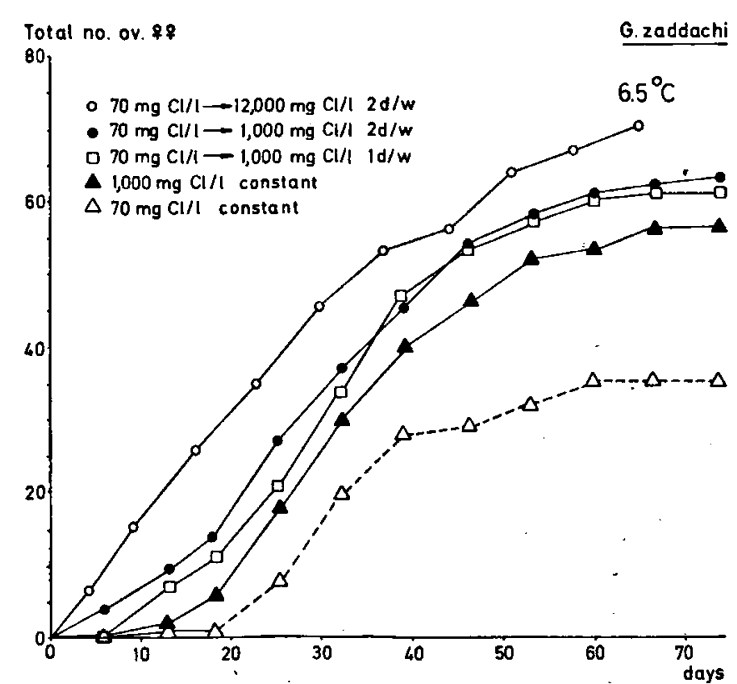

Fig. 26. The number of ovigerous females of Gammarus zaddachi at $6.5^{\circ} \mathrm{C}$ in waters with a constant chlorinity and in waters with a periodically rising chlorinity. The number of ovigerous females plotted in this figure is the cumulative number of ovigerous females. $70 \mathrm{mg} \mathrm{Cl} / 1 \rightarrow$ $12,000 \mathrm{mg} \mathrm{Cl} / \mathrm{l} 2 \mathrm{~d} / \mathrm{w}$ means: animals adapted to live in water of $70 \mathrm{mg} \mathrm{Cl} / 1$ are transferred to water of 12,000 $\mathrm{mg} \mathrm{Cl} / 1$ twice a week for one day.
XV.2b. Reproduction.

In this series the ovigerous females stay and hatch in the original basins. In counting the ovigerous females and illustrating the number of ovigerous females in a figure we followed the same methods as described in section XIV.2. The number of ovigerous females under the various conditions is indicated in fig. 26.

At $70 \mathrm{mg} \mathrm{Cl} / 1$ (and $6.5^{\circ} \mathrm{C}$ ) a fairly large number of females produced eggs. However, the development of the embryos appeared to be disturbed. After some time only a few embryos were alive in the brood pouch; the major part of the eggs died at a very early stage and remained in the brood pouch as a greyish amorphous mass. The last stage of the embryonic development, easily visible by the orange colour of the eggs, was never observed. It must therefore be concluded that $G$. zaddachi is unable to complete its reproductive cycle under laboratory conditions in water containing $70 \mathrm{mg} \mathrm{Cl} / 1$ and $35 \mathrm{mg} \mathrm{Ca} / \mathrm{l}$, at $6.5^{\circ} \mathrm{C}$.

The effect of a periodical rise in salinity is quite remarkable. A stay of 24 hours in water of 1000 
$\mathrm{mg} \mathrm{Cl} / 1$ alone is enough to raise the reproduction to the same level as in water with a constant chlorinity of $1000 \mathrm{mg} / \mathrm{l}$. A periodical rise to $12,000 \mathrm{mg} \mathrm{Cl} / 1$ has an even greater effect. Not only do populations under these conditions produce more ovigerous females, but the number of embryos that develops into juveniles is also much higher than in populations living at a constant chlorinity of $1000 \mathrm{mg} / 1$.

Differences in the mortality rate found in the various experimental conditions were very small. Periodical increases in salinity produce only a slight reduction in mortality.

\section{XV.3. Survival of juveniles at low salinities}

The question posed in this experiment is identical to that described for $G$. chevreuxi in section XIV.3. At an age of 3 to 5 days, juveniles born in water of $1000 \mathrm{mg} \mathrm{Cl} / 1$ and $6.5^{\circ} \mathrm{C}$, were transferred to water with $40,150,400,8000$, and 12,000 $\mathrm{mg} \mathrm{Cl} / \mathrm{l}$, respectively. Since adults can survive in lower chlorinities at low temperatures only (figs. 22-24), a temperature of $6.5^{\circ} \mathrm{C}$ was chosen for this experiment.

As in the case of adults, mortality appeared to increase with decreasing salinity (fig. 27). In the first two months, the survival rate is almost identical to that observed in adults under identical salinity conditions. However, as in the case of G. chevreuxi, those animals that survive in the first two months, also survive in the third and fourth months.

For the statistical significance of the results, see fig. 28.

\section{XV.4. Statistical significance of the results}

Two series of experiments concerning the survival rate of adults of Gammarus zaddachi were carried out, one with duplicate basins and one with a single basin for each condition.

In the first series the differences in life span between the originals and the controls have been checked, as well as the differences in life span between populations under different conditions; both differences were significant. So the model used was realistic.

In the second series, with a single basin per condition, the differences in life span observed in the different basins are also significant. However, here it is uncertain whether variations between the

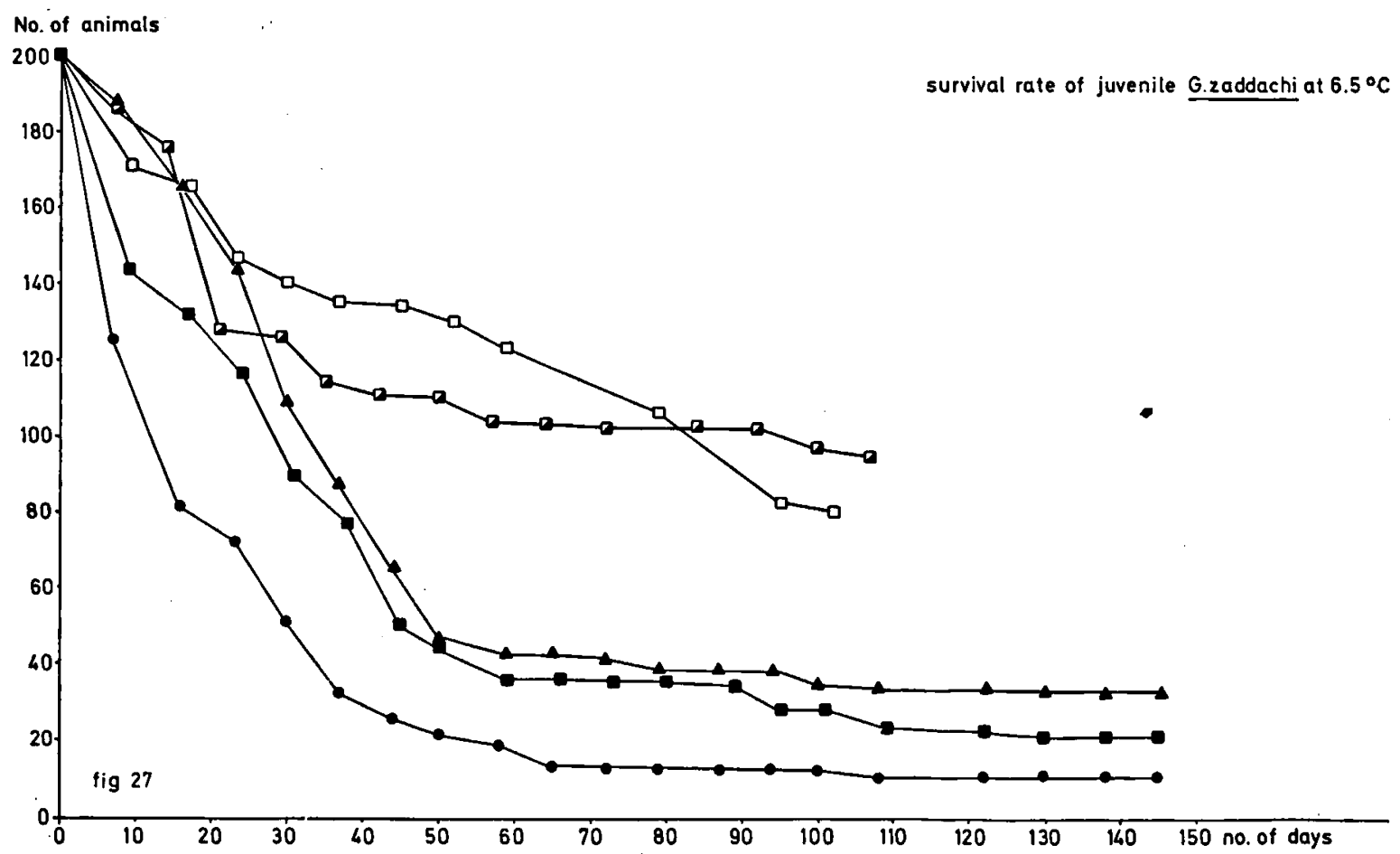

Fig. 27. The survival rate of juveniles of Gammarus zaddachi at a temperature of $6.5^{\circ} \mathrm{C}$ in waters of various salinities. For further explanation see fig. 18. 
Adults of Gammarus zaddachi: series 1

$\begin{array}{cccccl}1 & \longmapsto & -1 & & & \\ 6.5 & 6.5 & 6.5 & 6.5 & 6.5 & { }^{\circ} \mathrm{C} \\ 70 & W_{2} & W_{3} & W_{1} & 1000 & \mathrm{mg} \mathrm{Cl} / 1 \\ 35.6 & 39.2 & 40.3 & 46.5 & 46.7 & \text { mean length of life (in days) }\end{array}$

Adults of Gammarus zaddachi: series 2

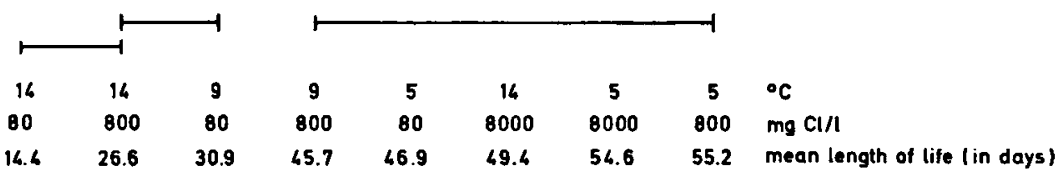

Juveniles of Gammarus zaddachi

\begin{tabular}{lccccl}
6.5 & \multicolumn{1}{c}{1} & \multicolumn{1}{c}{1} & \\
40 & 150 & 400 & 8000 & 12000 & $\mathrm{mg} \mathrm{Cl} / 1$ \\
22.3 & 37.3 & 43.4 & 63.4 & 66.8 & mean length of life (in days)
\end{tabular}

Fig. 28. Comparison of the various temperature/chlorinity combinations concerning their effect on the mean length of life of Gammarus zaddachi using statistical analysis as explained in section XIII. The three series of experiments, one with adults in duplicate basins, one with adults in single basins and one with juveniles in duplicate basins are tested individually. The temperature/chlorinity combinations used in the laboratory experiments together with the mean length of life found at the various combinations are ranged in order of increasing mean length of life. Combinations overlapped by the same horizontal line caused no significant differences in mean length of life. W1 $=$ animals adapted to live in water of $70 \mathrm{mg} \mathrm{Cl} /$ transferred to water of $1000 \mathrm{mg} \mathrm{Cl} / \mathrm{l}$ for 1 day once a week. W2 = id., for 1 day twice a week. W3 = id., to water of $12,000 \mathrm{mg} \mathrm{Cl} / 1$ for 1 day twice a week.

basins are due to the different experimental conditions or to variations that can exist even between basins with the same condition. This unreliability we must keep in mind when comparing the length of life under different conditions.

The results of comparison, always of pairs of the various conditions, are illustrated in fig. 28. As could be expected since the experiments of the first series were done at the favourable temperature of $6.5^{\circ} \mathrm{C}$, hardly any differences in mean length of life were found here. In the second series we found two completely disjoint groups: a group of conditions combining high temperature and low chlorinity, causing a short mean length of life, and a group characterized by high salinity and/or low temperature resulting in a high survival rate.
XVI. SYNTHESIS OF THE YEARLY MIGRATION CYCLE FROM FIELD OBSERVATIONS AND LABORATORY EXPERIMENTS

\section{XVI.1. Gammarus chevreuxi}

The limnic part of the river can be occupied at relatively low temperatures during the autumn H.W.S. Rearing experiments proved that limnic conditions, which are generally less favourable for this species, are best tolerated at low temperatures. During the equinoctial spring tides in spring the number of upstream migrants is much smaller.

The limnic reaches are mainly occupied by juveniles and preadults. Adults migrate less far in the upstream direction and start migrating downstream immediately after the period with H.W.S. 
When young animals have developed into adults, they start moving downstream. Adults are found in the estuarine parts or in those limnic areas that are influenced by mixohaline waters for a few days a month. Laboratory experiments did not prove that young juveniles have a higher tolerance for freshwater conditions than young adults. However, these experiments do not exclude the possibility that old juveniles and preadults are able to stand up better to these conditions.

The highest reproduction is found in the estuary. In limnic areas regularly influenced by mixohaline water the reproduction rate is a little lower. Temperature changes, as occurring in the Dourduff, do not play an important role. Reproduction reaches its maximum in January. February and March but goes on during the summer months at a much lower level. In winter, at temperatures from $6^{\circ}$ to $9^{\circ} \mathrm{C}$, females in completely fresh areas can produce eggs but no offspring; immediately after oviposition they migrate downstream. In the mixohaline parts of the river, eggs can develop into juveniles in the colder part of the year. In laboratory experiments no juveniles were found either at chlorinities below $400 \mathrm{mg} / 1$ or at $5^{\circ} \mathrm{C}$. At chlorinities of $400 \mathrm{mg} / 1$ or more juveniles were found both at $9^{\circ} \mathrm{C}$ and $14^{\circ} \mathrm{C}$.

\section{XVI.2. Gammarus zaddachi}

Except in December, the population always stays in areas with marine influences. Extensive upstream migration only takes place in autumn; upstream migration in spring is of minor importance. In the Dourduff, winter temperatures vary from $6^{\circ}$ to $9^{\circ} \mathrm{C}$ and summer temperatures from $15^{\circ}$ to $20^{\circ} \mathrm{C}$. In laboratory experiments a salinity of $80 \mathrm{mg} \mathrm{Cl} / 1$ was tolerated at $5^{\circ} \mathrm{C}$ only; a rise in temperature requires a rise in salinity; $14^{\circ} \mathrm{C}$ can only be endured at salinities above $800 \mathrm{mg} \mathrm{Cl} / 1$.

From the size difference between upstream and downstream migrating animals it can be deduced that young animals penetrate deeper into the limnic reaches than adults. Laboratory experiments do not give a decisive answer to the question whether juveniles at the age of these upstream migrating animals have a greater tolerance of low salinities than adults.

In the Dourduff, reproduction only takes place in the estuary during the months of January, February and March. No reproduction was observed in completely freshwater areas. In experiments at a salinity of $70 \mathrm{mg} \mathrm{Cl} / 1$ and $6.5^{\circ} \mathrm{C}$ embryonic development appeared to be disturbed. Moreover, no offspring was ever found at $80 \mathrm{mg} \mathrm{Cl} / 1$ and $5^{\circ} \mathrm{C}$. In experiments at $14^{\circ} \mathrm{C}$ reproduction was only observed at a chlorinity of $8000 \mathrm{mg} / 1$, so $14^{\circ} \mathrm{C}$ appeared to be too high a temperature for the lower salinities. At $6.5^{\circ} \mathrm{C}$ a periodical rise in salinity caused a sharp increase in the numbers of ovigerous females and made complete embryonic development possible. Obviously, summer temperatures in the Dourduff combined with the salinities found in the estuary, are too high to make reproduction possible. Likewise, winter temperatures in the limnic parts are too high to ensure reproduction even at those periods when a marine influence can be perceived.

The migration of $G$. chevreuxi and G. zaddachi is illustrated in a diagrammatic model (figs. 29 and 30).

\section{DISCUSSION}

XVII.1. The migration of G. zaddachi in the river Slack as compared to that in the Dourduff

Some differences in physical factors exist between the Dourduff and the Slack (see Dennert et al., 1969). In the Dourduff, winter temperatures vary from $6^{\circ}$ to $9^{\circ}$ and in the Slack from $3^{\circ}$ to $7^{\circ} \mathrm{C}$. The $\mathrm{Ca}$ content in the Dourduff varies from 13 to $30 \mathrm{mg} / \mathrm{l}$. The water in the Slack, which flows through a calcareous area, contains about $100 \mathrm{mg} \mathrm{Ca} / 1$ (see Dennert \& van Maren, 1974), and consequently has a higher $\mathrm{pH}$ than the Dourduff water. Furthermore, the slope in the limnic parts of the Dourduff is much steeper than in the Slack. Therefore, at H.W.S. mixohaline waters in the Dourduff can penetrate no more than one kilometre into the limnic area. In the Slack an important freshwater tidal area develops at H.W.S., where the direction of the water current reverses; in the Dourduff this is hardly ever observed. As far as salinity is concerned, station I in the Slack is comparable with stations I and II in the Dourduff, and stations II and III in the Slack with stations III and VI in the Dourduff, respectively.

The data obtained give no reason to suppose that differences in migration pattern exist between the populations in both river systems. However, in the Dourduff $G$. zaddachi lives near the southern limit of its distribution area. To endure the rather high temperatures in the Dourduff, the species has to live at higher salinities than in the Slack. No reproduction can take place in the limnic areas of the river Dourduff. The temperatures only oc- 


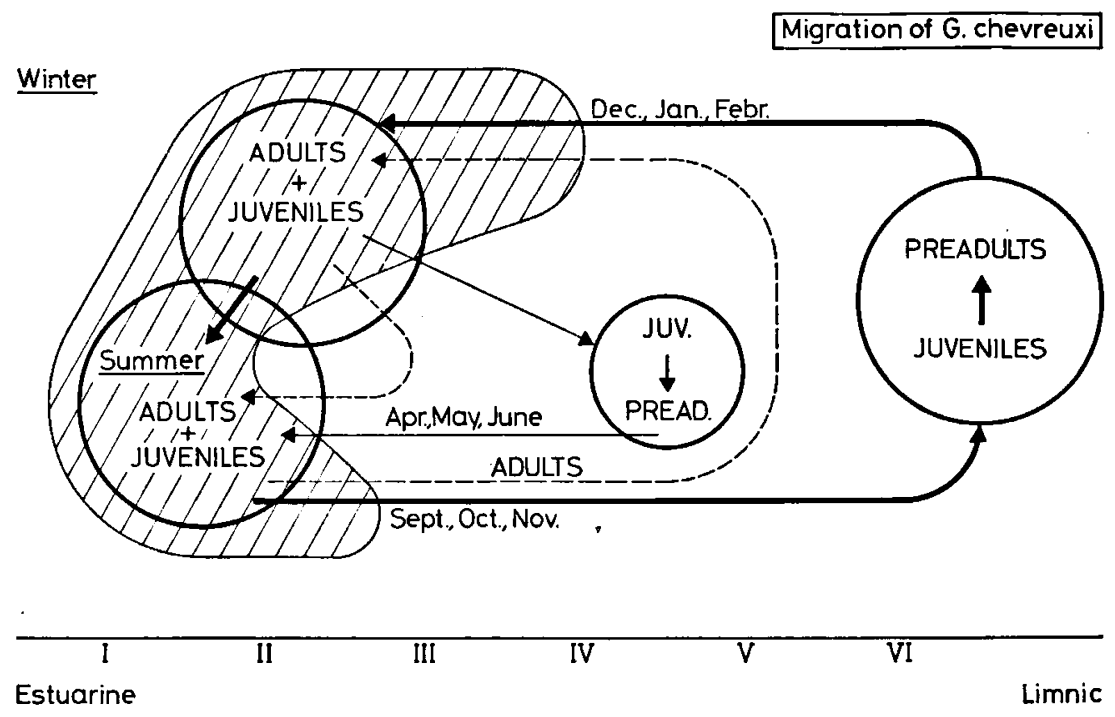

Fig. 29. Diagrammatic representation of the yearly migration cycle of Gammarus chevreuxi deduced from field observations and laboratory experiments. The stations (in Roman numerals) are indicated at the base of the figure. The time is roughly indicated in the figure itself. Circles indicate important concentrations of animals. The hatched area indicates time and place of important reproductive activity. Uninterrupted arrows indicate the direction of migration; dashed arrows refer to the secondary movements of adults.

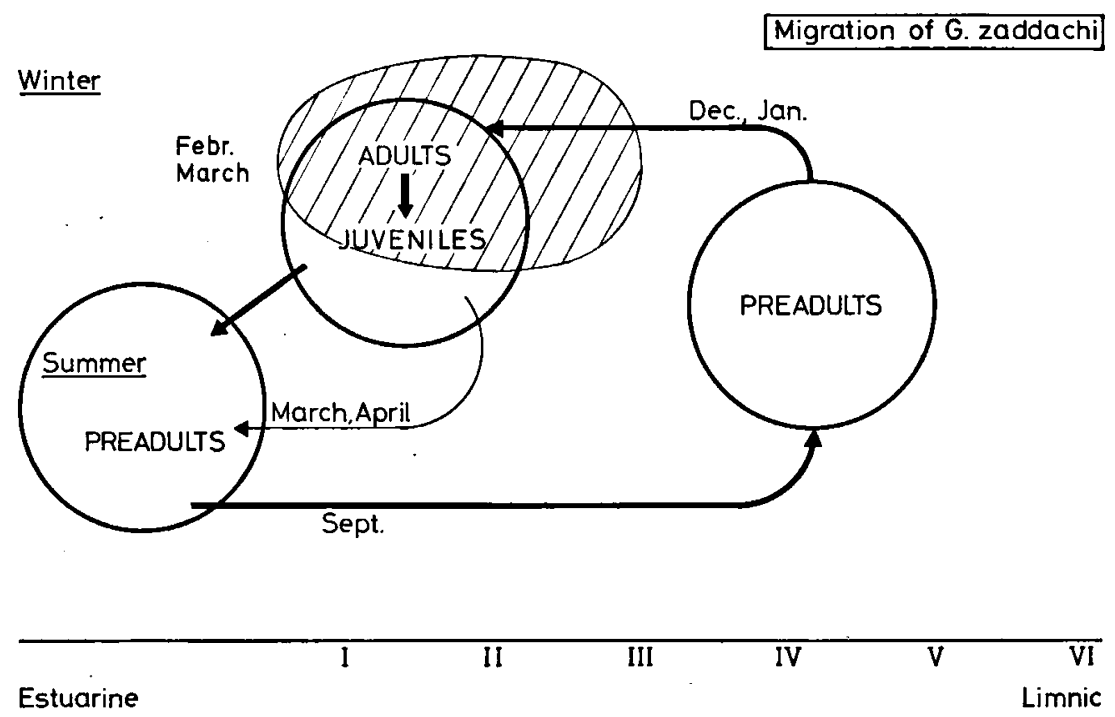

Fig. 30. Diagrammatic representation of the yearly migration cycle of Gammarus zaddachi as concluded from field observations and laboratory experiments. For explanation see fig. 29.

casionally drop below $7.5^{\circ} \mathrm{C}$, a temperature given by Dennert et al. (1969) and Dennert \& van Maren (1974) as the maximum temperature at which reproduction is possible in the limnic parts of the Slack.

Moreover, in contrast to the situation in the Slack, in laboratory experiments in limnic Dourduff water reproduction was neither found at $6.5^{\circ} \mathrm{C}$ nor at $5^{\circ} \mathrm{C}$. It may be that the $\mathrm{Ca}$-ion factor plays an important role here. Sutcliffe (1968) demonstrated that at $23 \mathrm{mg} \mathrm{Na} / \mathrm{l}$ (i.e. at a concentration comparable to the situation in the Dourduff) the ion uptake mechanism of $G$. zaddachi was saturated to a value of only $50 \%$; the presence of 80 to $160 \mathrm{mg} \mathrm{Ca} / \mathbf{l}$ (i.e. the concentration in the Slack) raised the ion uptake to $160 \%$ of the original value. This difference in $\mathrm{Ca}$ content in both river systems may be a second factor that enables 
G. zaddachi to penetrate much further into the limnic parts of the Slack than it does into the Dourduff.

\section{XVII.2. The migration pattern of $G$. chevreuxi and G. zaddachi in the Dourduff}

In principle, both species show the same migration pattern. Gammarus chevreuxi can withstand the relatively high water temperatures in the Dourduff better than Gammarus zaddachi. Like the other species $G$. chevreuxi can withstand limnic conditions better at lower temperatures, but nevertheless juveniles and preadults can survive for quite a long time in the limnic parts even when temperatures rise to some extent. The upstream migration of Gammarus chevreuxi in spring is of far more importance than that of G. zaddachi.

Unlike the other species, $G$. chevreuxi can produce eggs in the limnic parts of the Dourduff, but the development of the embryos requires a higher salinity. Summer temperatures are not too high to prevent $G$. chevreuxi from reproducing in areas with a periodical marine influence. Since $G$. chevreuxi can reproduce throughout the whole year, the population contains animals of all ages. Consequently, the migration pattern of the population is not uniform. The population shows two migration cycles a year, and so in spring we can observe two generations migrating in opposite directions and passing each other at the level of stations III and IV. This results in a spatial gap between the old and new generations at stations III and IV.

Since $G$. zaddachi reproduces in a limited period only, the whole population is of about the same age, and shows a uniform migration pattern. The population is not dispersed throughout the river system as in $G$. chevreuxi, but migrates as a sharply demarcated mass.

\section{XVII.3. The significance of the migration}

Many marine and brackish water crustaceans exhibit migratory activities once or several times during their lifetime e.g. Portunus holsatus and Eriocheir sinensis (cf. Verwey, 1958) Penaeus duorarum and $P$. aztecus (cf. Hughes, 1969) Crangon crangon (cf. Havinga, 1930) and Palaemonetes varians (cf. Antheunissen et al., 1971). These migrations always result in changes in the temperature/salinity conditions of the environment. During the summer months, the species mentioned above migrate to shallow, less saline areas and return to the open sea in winter.

Like G. zaddachi, a number of species in the North Sea, such as Hyas arenarius, Pandalus mon- tagui and Crangon allmani (cf. Verwey, 1957) which have their southern distribution limit in the North Sea, move to relatively fresher water in winter. Whether a population of a species migrates into relatively less saline waters during the summer or the winter months, depends on the temperatures at which low salinities are tolerated best and therefore also on the part of the total distribution area of the species, occupied by the migrating population under study.

Changes in temperature cause a change in the osmoregulatory pattern; the relation is very complex and differs in the various species (Verwey, 1957). Moreover, within one species various different physiological races can be found (Weeber \& Spaargaren, 1970). Likewise, temperature dependent changes in osmoregulation can vary from winter to summer (Dehnel, 1962; Todd, 1963); very often different reactions can be found within one individual between the various stages of its life cycle (Williams, 1960).

It is often difficult to discern which part of the osmoregulatory curves is favourable at the various conditions (see the data of Verwey, 1957). Weeber \& Spaargaren (1970:113) mention two possibilities: "It is conceivable that under a particular set of environmental conditions the osmoregulatory requirements of an animal may be satisfied by two possible regimes: a) regulation, with the possible advantage of a relatively constant blood osmolarity, and b) conformity, with the possible advantage of a relative constancy in the osmotic gradient across the body wall".

None of the migrating species mentioned is able to complete its life cycle in completely fresh water. Usually reproduction takes place in the more haline parts of their distribution areas (Scholles, 1933; Broekema, 1941; Williams, 1960; Dennert et al., 1969). Kinne, 1953, in G. duebeni, and Vlasblom \& Bolier, 1971, in Chaetogammarus marinus found that the embryonic stages did not develop at low salinities and that the juveniles and adults have a higher salinity tolerance. As a rule, postlarvae and juveniles occupy the lowest salinities (Williams, 1960; Tabb et al., 1962; Hughes, 1969; Dennert et al., 1969).

However, the fact that brackish water animals penetrate into water with lower salinities at the particular stage of their development and the particular temperature at which they can tolerate these silinities best (as far as this can be found from rearing experiments or can be argued from osmoregulatory data) does not give a complete explanation of the migration pattern described. The 
fact remains that these animals move to unfavourable salinity conditions, and we must therefore conclude that other abiotic and biotic factors play an important role.

Seen in the light of evolution, these migration patterns fit into the theory of the occupation of fresh water from the sea.

Beadle \& Cragg, 1940, studied the adaptation to freshwater conditions in a series of gammarids covering a range from marine to completely freshwater species. They gave the following outline of the evolution within this group:

- In the first instance the high internal concentration is maintained by active uptake of ions. (Shaw, 1961, defined this mechanism as: (a) a reduction of the permeability and (b) an increase of the affinity of the uptake mechanism for the various ions.) - As a second step they found a renal salt absorption (hypotonic urine) and a reduction of the internal concentration. (Sutcliffe (1968) studied the brackish water species G. duebeni, G. zaddachi and $G$. tigrinus. He found a strongly reduced permeability comparable to that in real freshwater species. The production of urine had decreased and urine was hypotonic. The affinity of the uptake mechanism for sodium had increased by a factor 10 in comparison to marine species, but was still a factor 10 lower than in real freshwater species.)

This makes it clear how Gammarus zaddachi is able to live in the estuary. The species is still able to produce isotonic urine under brackish conditions (Lockwood, 1962). Because of the very reduced permeability, sudden great changes in the external concentration are buffered in the body fluid. The low permeability, the adapted urine production and the increased affinity for sodium ions enables the species to live under limnic conditions for quite a long time. The affinity for sodium ions is still not high enough to live constantly under freshwater conditions and therefore the species runs risks during the moults or at unfavourable temperatures (Lockwood \& Andrews, 1969, for G. duebeni).

\section{XVII.4. Use of the tidal currents for migration}

Many of the Crustacea mentioned, like many other groups of animals, use tidal movements for their migration (for references see Verwey, 1958 and 1960).

Tidal currents can be used in two different ways, viz. (1) The animals are carried away by a tidal current and settle when the current reverses.
(2) The animals move actively and the tidal currents serve for orientation only. In these actively swimming animals, a turn of the tide causes a change in rheotropic response. On one tidal current their reaction is positive rheotropic, on the inversed current it is negative rheotropic. Animals that migrate twice during their life cycle usually show a reversal in their reaction to tidal movements, resulting in a migration in two opposite directions.

Both $G$. chevreuxi and G. zaddachi are carried away by the downflowing river water or by the incoming tide at H.W.S. as described in section V. It is impossible to say from our field observations how the animals distinguish between these incoming and outgoing water currents. In view of the fact that at a certain locality one part of the population is migrating downstream while another part is going in the opposite direction, it must be concluded that the origin of this reversal in reaction to certain environmental factors at a certain age must be sought in the animals themselves. A new series of laboratory experiments is planned to investigate how $G$. chevreuxi and $G$. zaddachi distinguish between the different water currents.

\section{ACKNOWLEDGEMENTS AND RESPONSABILITIES}

The authors are greatly indebted to the Station Biologique, Roscoff, France and to Mr. and Mrs. Braouézec, the owners of the land alongside the investigated area, where our team received hospitality during the fieldwork. Many thanks are due to Miss Drs. M. J. van Maren for her kind assistance in sampling the standing crop; to Prof. Dr. J. H. Stock and Drs. H. G. Dennert for their critical remarks and useful discussions; to Drs. R. Potharst of the Mathematisch Centrum Amsterdam for his statistical advices. Special thanks are due to Mr. H. Mittelberg of the I.T.Z. for his technical assistance in all stages of the work and to Mr. J. Zaagman for making the figures. The fieldwork has been made possible by grants of the University of Amsterdam.

Although the present paper is, we hope, a unity, each of the authors took special care for certain sections of it. So most of the fieldwork was done by Mr. Girisch and Mr. Petersen, often assisted by Mr. Dieleman. Mr. Dieleman was responsable for the laboratory experiments. The project, on which the first three authors were working for their masters degree, was supervised and coordinated by Dr. S. Pinkster. The final manuscript was prepared by Drs. H. B. Girisch and Dr. S. Pinkster in close cooperation with Mr. J. Dieleman.

\section{REFERENCES}

Antheunissen, L. J., J. J. Lammens \& N. P. Van den HOVEN, 1971. Diurnal activities and tidal migrations of the brackish water prawn Palaemonetes varians (Leach) (Decapoda, Caridea). Crustaceana, 21 (2): 
203-217.

Beadle, L. C. \& J. B. Cragg, 1940. Studies on adaptation to salinity in Gammarus spp. I. Regulation of blood and tissues and the problem of adaptation to fresh water. J. exp. Biol., 17 : 153-163.

Beld, F. A. J. VAN DEN, 1973. Cycles annuels de Gammarus duebeni duebeni Liljeborg, 1852, et de Gammarus pulex pulex (Linné, 1758) le long de la côte française du Boulonnais. Bull. zool. Mus. Univ. Amsterdam, 3 (13) : 79-98.

Broekema, M. M. M., 1941. Seasonal movements and the osmotic behaviour of the shrimp Crangon crangon. Archs néerl. Zool., 6 (1) : 1-100.

Bulnheim, H. P. 1972. Vergleichende Untersuchungen zur Atmungsphysiologie euryhaliener Gammariden unter besonderer Berücksichtigung der Salzgehaltsanpassung. Helgoländer wiss. Meeresunters., 23 (4) : 485-534.

DeHNel, P. A., 1962. Aspects of osmoregulation in two species of intertidal crabs. Biol. Bull. mar. biol. Lab. Woods Hole, 122 (2) : 208-227.

DENNERT, H. G., 1974. Tolerance differences and interspecific competition in three members of the amphipod genus Gammarus. Bijdr. Dierk., 44 (1) : 83-99.

Dennert, H. G., A. L. Dennert, P. Kant, S. Pinkster \& J. H. STOCK, 1969. Upstream and downstream migrations in relation to the reproductive cycle and to environmental factors in the amphipod, Gammarus zaddachi. Bijdr. Dierk., 39 : 11-43.

Dennert, H. G., \& M. J. Van Maren, 1974. Further observations on the migration of Gammarus zaddachi Sexton (Crustacea, Amphipoda) in a French stream. Bull. zool. Mus. Univ. Amsterdam, 3 (20) : 157-167.

Gras, J. M. J. F. \& A. M. J. MAASen, 1971. Les Gammaridés des eaux continentales et saumâtres du SudEst de la région armoricaine et du Nord du Bassin d'Aquitaine. Bijdr. Dierk., 41 (1) : 52-60.

HARTOG, C. DEN, 1964. The amphipods of the deltaic region of the rivers Rhine, Meuse and Scheldt in relation to the hydrography of the area. Part III: Gammaridae. Neth. J. Sea Res., 2 (3) : 407-457.

HavingA, B., 1930. Der Granat in den holländischen Gewässern. J. Cons. perm. int. Explor. Mer, 5 : 57-87.

Hughes, D. A., 1969. Responses to salinity change as a tidal transport mechanism of pink shrimp, Penaeus duorarum. Biol. Bull. mar. biol. Lab. Woods Hole, 136 (1) : 43-53.

,- 1970 . Some factors affecting drift and upstream movements of G. pulex. Ecology, 51 (2) : 301-305.

KINNE, O., 1953. Zur Biologie und Physiologie von Gammarus duebeni Lillj. Z. wiss. Zool., 157 : 427-491.

,- 1960 . Growth, moulting frequency, heart beat, number of eggs and incubation time in Gammarus zaddachi exposed to different environments. Crustaceana, 2 (1) : 26-36.

Lockwood, A. P. M., 1962. The osmoregulation of Crustacea. Biol. Rev., 37 : 257-305.

Lockwood, A. P. M. \& W. H. R. ANDREwS, 1969. Active transport and sodium fluxes at moult in the amphipod Gammarus duebeni. J. exp. Biol., 51 : 591-605.

Mangelsdorf, P. C., Jr. 1967. Salinity measurements in estuaries. Publs Am. Ass. Advmt Sci., 83 : 71-79.

Meyering, M. P. D., 1972. Experimentelle Untersuchungen zur Drift und Aufwanderung von Gammariden in Fliessgewässern. Arch. Hydrobiol., 70 (2) : 133-205.

Minshalt, G. W. \& P. V. Winger, 1968. The effect of reduction in stream flow on invertebrate drift. Ecology, 49 (3) : 580-582.

MüllER, K., 1965. An automatic stream drift sampler. Limnol. Oceanogr., 10 (3) : 483-485.

,- 1970 . Tages- und Jahresperiodik der Drift in Fliessgewässern in verschiedenen geografischen Breiten. Oikos, 13 : 21-44.

NoOter, K. \& F. Liebregts, 1971. Une recherche sur le taux de chlorinité de l'eau interstitielle dans le lit de La Slack. Bijdr. Dierk., 41 (1) : 23-30.

Salmon, J., 1959. Contribution à la biologie des eaux saumâtres: Etude bionomique de la partie terminale de la rivière L'Ic à Binic (Côtes du Nord). Bull. Soc. scient. Bretagne, $34: 81-126$.

SCHOLLES, W., 1933. Uber die Mineralregulation wasserlebender Evertebraten. Z. vergl. Physiol., 19 : 522.

Sexton, E. W., 1924. The moulting and growth-stages of Gammarus, with descriptions of the normals and intersexes of G. chevreuxi. J. mar. biol. Ass. U.K., 13 (2) : 340-401, text-figs. 1-4, pls. I-XXI.

SHAW, J., 1961. Sodium balance in Eriocheir sinensis (M. Edw.). The adaptation of the Crustacea to fresh water. J. exp. Biol., 38 : 153-162.

SPOONER, G. M., 1947. The distribution of Gammarus species in estuaries. 1. J. mar. biol. Ass. U.K., 27 : $1-52$.

SuTCLIFFE, D. W., 1968. Sodium regulation and adaptation to fresh water in gammarid crustaceans. J. exp. Biol., 48 : 359-380.

- , 1972. An examination of subspecific differences in the merus of the fifth walking leg of the amphipod Gammarus duebeni Lilljeborg. Freshw. Biol., 2 : 203216.

TABB, D. C., D. L. Dubrow \& A. E. Jones, 1962. Studies on the biology of the pink shrimp, Penaeus duorarum Burkenroad, in Everglades National Park, Florida. Fla. St. Bd. Cons., Univ. Miami Mar. Lab., Tech. Ser., 37 : 1-30.

ToDD, M. E., 1963. Osmoregulation in Ligia oceania and Idotea granulosa. J. exp. Biol., 40 : 381-392.

VERWEY, J., 1957. A plea for the study of temperature influence on osmoregulation. Année biol., 33: 129. 149.

-, 1958. Orientation in migrating marine animals and a comparison with that of other migrants. Archs néerl. zool., 13 (suppl.): 418-445.

,- 1960 . Uber die Orientierung wandernder Meerestiere. Helgoländer wiss. Meeresunters., 7 : 50-58.

- 1966. The role of some external factors in the vertical migration of marine animals. Neth. J. Sea Res., 3 (2) : 245-266.

Vlasblom, A. G. \& G. Bolier, 1971. Tolerance of embryos of Marinogammarus marinus and Orchestia gammarella (Amphipoda) to lowered salinities. Neth. J. Sea Res., 5 : 334-341.

WATERS, T. F., 1965. Interpretation of invertebrate drift in streams. Ecology, $46: 327-334$.

Weeber, R. E. \& D. H. SpaArgaren, 1970. On the influence of temperature on the osmoregulation of Crangon crangon and its significance under estuarine conditions. Neth. J. Sea Res., 5 : 108-120.

Williams, A. B. 1960 . The influence of temperature on osmotic regulation in two species of estuarine shrimps. Biol. Bull. mar. biol. Lab. Woods Hole, 119 :560-571. 